\title{
A Review on Novel Techniques for Chalcopyrite Ore Processing
}

\author{
Alafara A. Baba ${ }^{1,2, *}$, Kuranga I. Ayinla ${ }^{3}$, Folahan A. Adekola ${ }^{1}$, Malay K. Ghosh ${ }^{2}$, Olus hola S. Ayanda ${ }^{4}$, \\ Rafiu B. Bale ${ }^{5}$, Abdul R. She ik ${ }^{2}$, Sangita R. Pradhan ${ }^{2}$ \\ ${ }^{1}$ Chemistry Department, University of Ilorin, P. M. B. 1515, University of Ilorin, Ilorin, 240003, Nigeria \\ ${ }^{2}$ Hydro \& Electrometallurgy Department, Institute of Minerals and Materials Technology, Bhubaneswar, 751013, India \\ ${ }^{3}$ Chemistry Department, Institute of Basic and Applied Sciences, P.M.B. 1375, Kwara State Polytechnics, Ilorin, Nigeria \\ ${ }^{4}$ Department of Chemistry, Faculty of Applied Sciences, Cape Peninsula Univ ersity of Technology, P. O. Box 652, Cape Town, South \\ Africa \\ ${ }^{5}$ Geology and Mineral Sciences Department, University of Ilorin, P.M.B. 1515, University of Ilorin, Ilorin, 240003, Nigeria
}

\begin{abstract}
Chalcopyrite ores are usually processed by means of hydrometallurg ical or pyro metallurgical processes, but due to environmental aspects and the possibility of increased exploitation of mixed and lower grade ores and relatively small isolated deposits, there has been a worldwide upsurge of interest in the hydrometallurg ical processes of this ore as compared to pyrometallurgy. The different concentrates obtained through differential flotation in pyrometallu rgy are usually of poor quality with low metal recovery. This further makes pyrometallurgical processing of chalcopyrite very difficult and costly and rendered them difficult to commercialize. As a result, the metal value is preferably extracted directly from low grade ores through hydrometallurgical process. A detailed review of chalcopyrite deposits, production and consumption, mining, ore processing, steps involved in the pyrometallurgical and hydrometallurgical processing of copper as well as the dissolution kinetics and microbial studies of chalcopyrite ore were discussed.
\end{abstract}

Keywords Copper and Chalcopyrite, Ore processing, Hydrometallurgy, Pyrometallurgy, Dissolution Kinetics, Biohydrometallurgy

\section{Introduction}

Chalcopyrite is derived from the Greek words "chalkos", copper and "pyrites" strike fire and it is also known as copper pyrite (Szy manowski, 1996). It is a brassy to golden yellow color mineral and was first discovered in Polk Country in 1847. The first mine opened in 1850 and first smelter was opened in 1885 and was operated until 1987 when it was closed due to unfavourable economics (Rotuska and Chimje leniki, 2008). Chalcopyrite $\left(\mathrm{CuFeS}_{2}\right)$ is the most common copper bearing mineral on earth (Nesse, 2000). Chalcopyrite is of primary importance and occurs in igneous and metamorphic rock and in metalliferous veins (McGraw-Hill, 1998). It contains many minerals including copper, zinc, sulfur and iron. All were produced at different times. At first, copper was the most important product and sulfur was a poisonous waste product. By the 1980 's, $70 \%$ of production value came from the production of sulfuric acid (Hyvarinen et al. 2003). It is not only the most abundant of copper sulfides, but also the most stable

* Corresponding author:

alafara@unilorin.edu.ng (Alafara A. Baba)

Published online at http://journal.sapub.org/mining

Copyright (C) 2012 Scientific \& Academic Publishing. All Rights Reserved minerals because of its structural configuration (face-centered tetragonal lattice). It is also the most refractory to hydrometallurgical processing (Haver and Wang, 1971). Chalcopyrite is the primary mineral which by alteration and successive enrich with copper produces the series, starting with chalcopyrite and going through bornites $\left(\mathrm{Cu}_{5} \mathrm{FeS}\right)$, covellite $(\mathrm{CuS})$, chalcocite $\left(\mathrm{Cu}_{2} \mathrm{~S}\right)$ and ending rarely as native copper (Brantley, 2003).

At present, there are basically two main methods employed worldwide in order to process chalcopyrite for metal production. The most important one is the conventional - pyrometallurgy method: comprised numerous types of shaft and flash technologies, which consists of crushing, grinding, flotation, smelting, refining and electro-refining. This method is applied to sulphide flotation concentrates rather than ores and is economically feasible for copper rich feed for large scale operations. A second method is hydrometallurgy and this method is applied to the rest of the world's primary copper production. Hydrometallurgy consists of crushing, leaching (non-oxidation leaching, atmospheric leaching and pressure leaching), solvent extraction and electrowinning. Hydrometallu rgical processing can be effectively applied to oxidized ores containing $\mathrm{CuO}, \mathrm{Cu}_{2} \mathrm{O}$, carbonates and some silicates, as well as sulfide ores with chalcopyrite as a 
predominant copper mineral. Hydro metallurgical methods are used in countries having readily available deposits with low copper content with sulphur of oxidized form at the same time (USA, Chile, Australia and Peru) (Majima et al. 1985). Hydrometallurgical processing of chalcopyrite concentrates has received considerable attention over the last three decades (Haver and Wang, 1971).

Approximately $70 \%$ of the world's copper reserves are contained in the mineral chalcopyrite (Thomas, 2009). Thus, chalcopyrite, the most common ore of copper, occurs and widely distributed in metallic veins associated with pyrite $\left(\mathrm{FeS}_{2}\right)$, phyrrhotite $\left(\mathrm{Fe}_{7} \mathrm{~S}_{8}\right)$, bornites $\left(\mathrm{Cu}_{5} \mathrm{FeS}\right)$, chalcocite $\left(\mathrm{Cu}_{2} \mathrm{~S}\right)$, sphalerite $(\mathrm{ZnS})$, galena $(\mathrm{PbS})$, calcite $\left(\mathrm{CaCO}_{3}\right)$, siderite $\left(\mathrm{FeCO}_{3}\right)$, dolo mite $\left(\mathrm{CaCO}_{3} \cdot \mathrm{MgCO}_{3}\right)$ etc. Many carry gold or silver and became an ore of those metals. Often in subordinate amount with large bodies of pyrite $\left(\mathrm{FeS}_{2}\right)$, making them serve as low-grade copper ores. Usually massive often making up golden sulfide mixture crystals over sphalerite surface (Szymanowski, 1996). Natural chalcopyrite has no solid solution series with any other sulfide minerals. There is limited substitution of $\mathrm{Zn}$ with $\mathrm{Cu}$ despite chalcopyrite having the same crystal structure as sphalerite $(\mathrm{ZnS})$. However, it is often contaminated by a variety of other trace elements such as $\mathrm{Co}, \mathrm{Ni}, \mathrm{Mn}, \mathrm{Zn}$ and $\mathrm{Sn}$ substituting for copper and $\mathrm{Fe}, \mathrm{Se}$ and As substitute for sulfur, and trace a mount of $\mathrm{Ag}, \mathrm{Au}, \mathrm{Pt}$, $\mathrm{Pd}, \mathrm{V}, \mathrm{Cr}, \mathrm{In}, \mathrm{Al}$ and $\mathrm{Sb}$ are reported. It is most likely that many of these elements are present in finely inter-grown mineral within the chalcopyrite (Hershel, 2011). A large portion of the copper produced in the world is obtained by the smelting of chalcopyrite and ores associated with it (Yin et al. 1995).

\subsection{Global Chalcopyrite Deposit}

Chalcopyrite deposits across the globe are as represented in Fig. 1. It is a fairly common mineral and therefore, only the finest of localities will be mentioned.

Large, well shaped crystals occur in numerous places in Cornwell (England) as well as Akita, Ugo and Tochigi prefectures, Japan. Many fine crystals occur in the northern section of Mexico. Certain occurrences are La Bufa, Chihuahua, Charcas, San Lu is Potosi and the Noche Buena mine, near Mazapil, Zacatecas Mexico (Hershel, 2011). The French Greek mine in Chester Co. Pennyslvania has produced huge crystal, many distorted and highly tarn ished. Large amount of chalcopyrite occurs with sphalerite $(\mathrm{ZnS})$, galena $(\mathrm{PbS})$ and marcasite in the Joplin District of Mis souri Okhlaho ma and Kansas, USA.

Chalcopyrite is widely distributed in the United States but usually in connection with other copper minerals in equal or greater amount found at Butte, Montana, Bingham, Utah, various districts in california, colorado, Arizona (Nevada, 2011). Many fine crystals occur in the northern section; certain occurrences are La Bufa, Chihuahua, Charcas - San Luis Potosi, and the Noche Buena mine near Mazapil, Zacatecas the sudburdy Canada. Chalcopyrite is also found in content metamorphic deposit in limestone (Bisbee, Arizona). Giant deposit crystals were found in Freirina, Northern Chile and also vast deposits are found in Northern Mexico (Hershel, 2011).

Chalcopyrite is the copper ore deposit of Falum, Sweden of Namagaland in South Africa. However, vast crystals or deposits occur in Ishiagu, Ebonyi State; South Eastern region of Nigeria (West Africa). High great chalcopyrite deposit can also be found in Baluba, East of Lusaka (Zambia).

A well shaped chalcopyrite crystal occurs in many places such as Akita, Ugo and Tochigi prefectures Japan (Chuck and Virg inia, 2011).

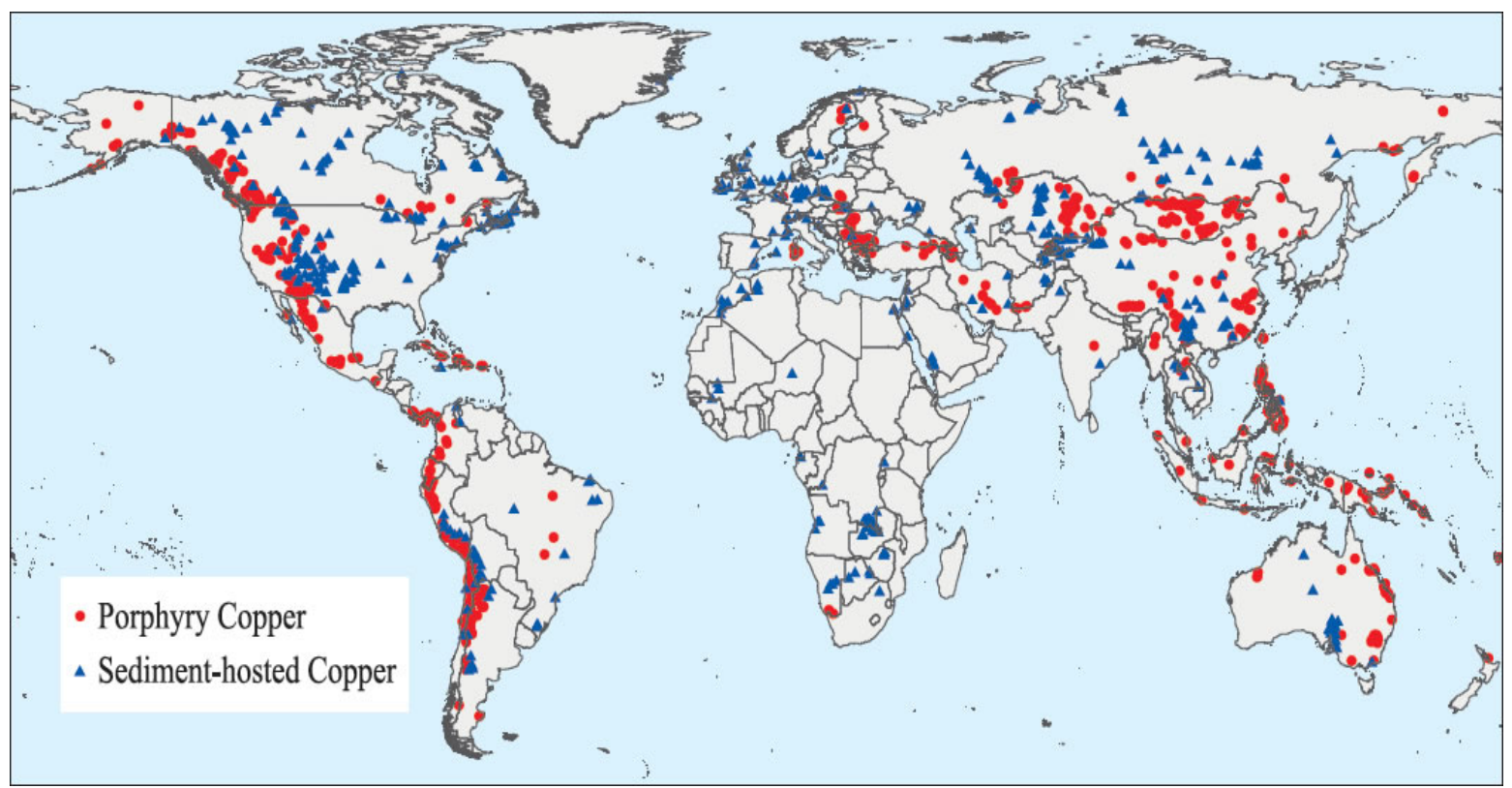

Figure 1. Chalcopyrite deposit across the Globe (Facts about copper, 2010) 
Large, well shaped crystals of chalcopyrite also occur in numerous places in Falum (Sweden), Rio Tinto (Spain), Mansfeld (Germany), Lukkulaisvaara Ultrabasic Massif, Olanga (Oulanka) River, Ounlanka Plutonic complex and Kare lia Republic (Northern Region, Russia).

\subsection{Chalcopyrite Ore Production}

The sulfide ore minerals including chalcopyrite $\left(\mathrm{CuFeS}_{2}\right)$, sphalerite $(\mathrm{ZnS})$, galena $(\mathrm{PbS})$ provide the major sources of the world's base metals $(\mathrm{Cu}, \mathrm{Zn}, \mathrm{Pb}$, respectively), whereas pyrite is virtually ubiquitous as a metalliferous mineral in sulfide ore deposits (Crang and Vanghan, 1994). The first step in recovering metal fro $m$ their mineral is that of finding ore-bodies in which metal sulfides are present in a sufficient quantity and as a result of oxidation of the sulfide mineral in nature weathering underground. The induced polarization exploration technique involves applying a series of current pulses to two electrodes inserted into ground and analyzing the induced voltage at two different electrodes also inserted into the ground (Jones, 1999). Valuable minerals are thus extracted from the ore by means of flotation separation, extractive metallurgy or leaching.

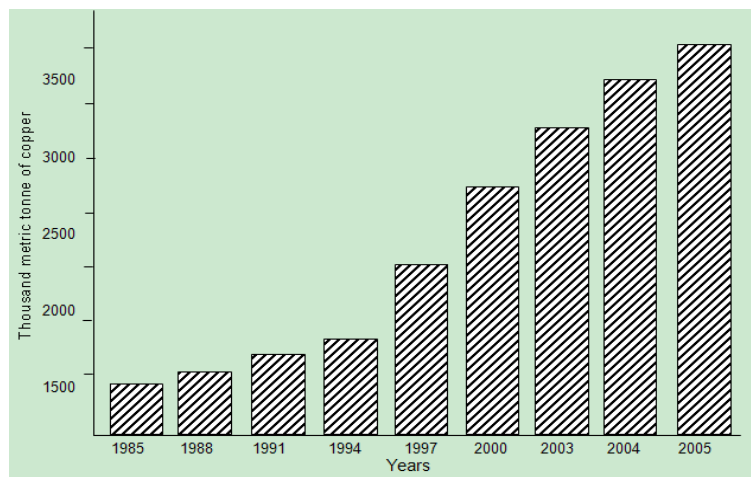

Figure 2. World T rend in (SX-solvent extraction) capacities from $1985-$ 2005 (Rotuska and Chimjeleniki, 2008)

\subsubsection{Flotation Separation}

Valuable mineral in an ore such as chalcopyrite ore can be separated from each other and from worthless gauge minerals by the froth flotation process. The process was developed in Australia at the start of the $20^{\text {th }}$ Century to treat the primary sulfidic silver/lead/zinc ore at Broken Hill (Woods and Doyle, 2000). Many approaches were pursued to solve the sulfide problem at Broken Hill before selective flotation was developed. The successful technology involve first crushing the ore, typically to a particle size of about 5 to 50 micrometer to liberate separate grains of the various valuable mineral and worth less gauge components. Then the particle is pulped with water and the surface of the mineral of the interest selectively made hydrophobic through the addition of organic specie which is term collector. Following this procedure, a stream of air bubbles is passed through the pulp; the bubbles attach to levitate the hydrophobic particles and are collected in a froth layer that disengages from the flotation cell by flowing over the weir of the cell. A frother such as a long chain alkyl alcohol is added to create a stable froth layer in the cell. The collector used at Broken Hill in the early days was eucalyptus oil derived from the leaves of the ubiquitous Australia "gum" tree. Following the success at Broken Hill, mining companies throughout the world rapidly adopted the flotation process (Young et al. 2003). Flotation also used to split copper and nickel sulfides and separate them from iron sulfides and gangue minerals. Cobalt appears in the nickel concentration and the cobalt is subsequetly recovered. Flotation has developed from the treatment of simple ores to the ever more complex ones that are being fund today. Thus, for example, the three metals in copper/lead/zinc ore are floated into three concentrates, each containing one of the metals (Pletcher et al. 1993).

\subsubsection{Extractive Metallurgy}

Metal sulfide flotation concentrates occur in a number of ways. These include using pyrometallurgy or smelting at high temperature. In this process, the sulfur in the metal sulfide is oxidized with air or oxygen to sulfur dioxide and molten matte is produced.

Flotation concentrates can also be processed using hydrometallurgy in which the metal sulfide is dissolved (leached) into an aqueous solution (Bergy and Yianatos, 2001). Most oxide of copper minerals dissolves readily in sulfuric acid so that leaching is reasonably straight forward. A concentrated, pure copper sulfate solution suitable for electrowinning is produced from the initial leach solution by selectively transferring the copper ion to an organic phase by a process known as solvent extraction and returning them again to an aqueous phase (Young et al. 2003). Complexing agents are dissolved in an organic solvent at low vapour pressure kerosene and this phase is intimately dispersed within the aqueous leach solution in a mixer-settler. The copper selectively complexes with the reagent and is transferred into the organic phase. The copper replace hydrogen ion in the complex and hydrogen ions are subsequently transferred to the aqueous phase. The two phases are allowed to separate in the settler section and then the aqueous acid solution termed the "raffinate" is recycled to ore leaching. The loaded organic phase is sent to a second mixer-settler where it is reacted with a strong aqueous sulfuric acid solution. Here, the copper is exchanged for hydrogen ions and transferred into the second aqueous phase from which the metal is efficiently recovered by electrolysis. The overall process of dissolution, solvent extraction and electrowinning is known as SX-EW. Fig. 3 shows a typical flow diagram of LX/SX/EW.

The commercial interest in the solvent extraction of copper from chalcopyrite began in the North American and was initially the result of leaching studies of low grade oxide minerals that were not available for upgrade and concentration by flotation technique. Their loss to waste dump represented poor management of natural resources and importantly a loss of potential revenue that the mining companies in the USA could not afford because of their labour cost and overall low mineralogical grades relative to 
other copper producing countries. With copper being an international traded commodity, the concept of producing the metal at lowest possible cost was important, otherwise, the copper industry in the US would be at significant disadvantages relative to other nations (Seward, 2001).

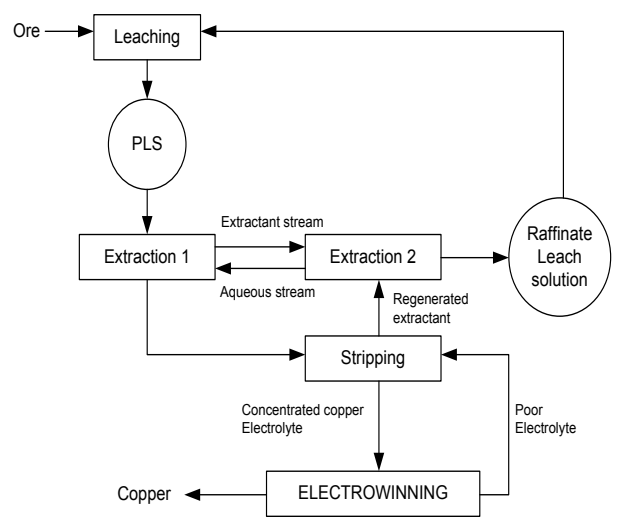

Figure 3. Typical flow diagram of LX/SX/EW (Bergy and Yianatos, 2001)

\subsubsection{Leaching}

Leaching is a heterogeneous reaction that takes place at the interface between a solid and liquid phase and sometimes a gaseous phase. At the boundary between the two phases, a diffusion layer is formed. The dissolution of mineral ore takes place through the following stages: (1) diffusion of reactant through the diffusion layer, (2) adsorption of the reactant on the solid, (3) chemical reaction between the reactant and the solid, (4) desorption of the product from the solid and (5) diffusion of the product through the diffusion layer. Any of these stages (1) - (5) may be the rate controlling step depending on its relative speed to the others as represented in Fig. 4.

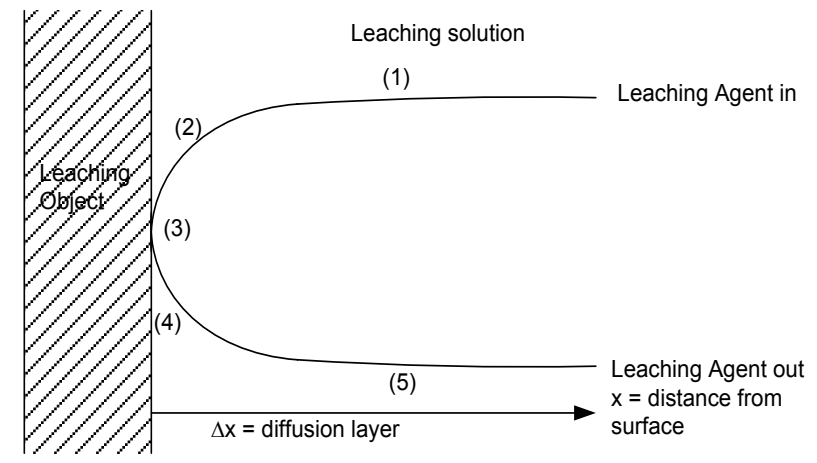

Figure 4. Basic sketch of a leaching process (Crest, 2000)

These processes are normally dominated by stage 1 and 5 , both of which involved diffusion. The rate of chemical reaction at the interface is much faster than the rate of diffusion of reactant to the interface. The following equations describe the relationship between dissolution and leaching time ( $\mathrm{t}), \mathrm{K}$ is the rate constant.

$$
(1-2 / 3 \alpha)-(1-\alpha)^{2 / 3}=K t
$$

Chemically controlled process is the opposite of the above mechanism type since the rate of chemical reaction is much slower than the rate of diffusion given by equation (2).

$$
1-(1-\alpha)^{1 / 3}=K t
$$

These processes strongly depend on temperature since the rate of chemical reaction increases with temperature, but independent of the agitation speed since diffusion plays an insignificant role in the process.

Mixed kinetic process is a hybrid of the two types as the chemical and diffusion rate will be of the same magnitude. Equation (3) summarizes this mechanism where " $b$ " is a direct function of surface reaction.

$$
\left(1-\frac{2}{3} \alpha\right)-(1-\alpha)^{\frac{2}{3}}+\frac{1}{b}\left[1-(1-\alpha)^{\frac{1}{3}}\right]=K t
$$

For practical purposes, $b$ is always equal to 1 and $\alpha$ is the fraction of the ore dissolved at a given leaching time (Crest, 2000).

\subsection{Chalcopyrite Ore Consumption}

Approximately $70 \%$ of the world's copper reserves are contained in the mineral chalcopyrite. Currently, copper is extracted from high-grade chalcopyrite through smelting a high temperature process with undesirable environmental side effects (Thomas, 2009)

The world's production (supply) and consumption (demand) of chalcopyrite (copper) have increased dramatically in the past 25 years. As large developing countries have entered the global market, demand for mineral commodities has increased. In the last 20 years, the Andean region of South America has emerged as the world most productive copper region. In 2007 , about $45 \%$ of the world's copper was produced from the Andes Mountain (USA). The United State produced 8\%, virtually all copper produced in the United State comes from Arizona, Utah, Mexico, Nevada or Montana in decreasing order of production.

The risk of distribution to the global copper supply is considered to be low because copper production is globally dispersed and is not limited to a single country or region due to its importance in construction and power transmission. However, the impact of any copper supply distribution would be high. The qualities of copper that have made it the material of choice for a variety of do mestic, industrial and high-technology applications have resulted in a steady rise in global copper consumption. US geological survey studies of copper consumption showed some interesting trends for the 1980 to 2008 time period. Copper consumption in emerging economies such as China and India rose considerably, whereas the consumption rate in industrialized economies such as the United States fell slightly until 2002. The United States was the leading copper consumer and artificially use about 16 percent of total world refined copper (about 2.4 million tonnes). In 2002, the United States was overtaken by China as the world's leading user of refined copper. The booming 
economy in China contributed to a tripling of its annual refined copper consumption during the 8 years from 1999 to 2007. The global consumption of copper from 1980 to 2008 is shown in Fig. 5.

Copper is one of the most widely recycled of all metals and approximately one-third of all copper consumed worldwide is recycled. Recycle copper and its alloy can be re-melted and used directly or further reprocessed to refined copper without losing any of the metals' chemical and physical properties (Dixon and Dre isinger, 2003).

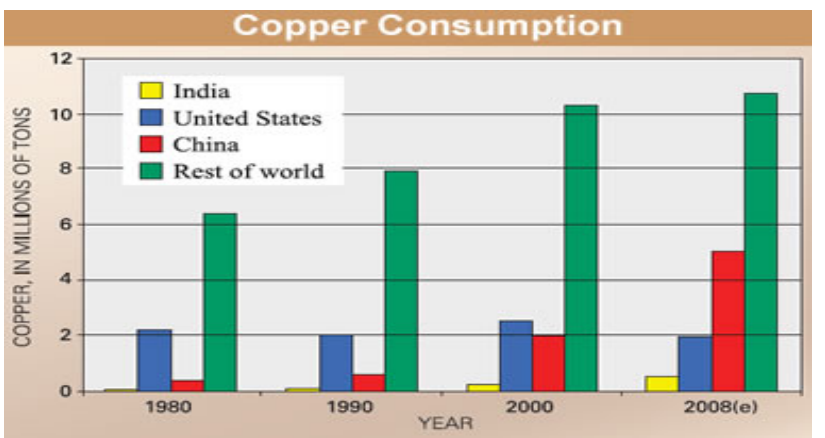

Figure 5. Global consumption of copper from 1980 - 2008 (USGS, 2009)

\subsection{Market Potentials and Industrial Applications of Copper}

Copper was one of the first metals ever extracted and used by humans and it has made vital contributions to sustaining and improving society since the dawn of civilization. As man learned to fashion his weapon from iron and steel, copper began to assume another roles. Being a durable metal and possession of great beauty, it is used extensively for household utensils, water pipe, marine uses and other purposes that required resistance to corrosion. Copper is easily stretched, molded and shaped. It is resistance to corrosion and conducts heat and electricity efficiently. The unusual ability of this mineral to conduct electric current account for its greatest use today (McGraw-Hill, 1998). As a result, copper was important to early human and continue to be a material of choice for a variety of domestic, industrial and high-technology applications today (USGS, 2009).

Copper producers all around the world are facing continuously increase demands, both economically and environmentally. During the last decade, the production chain of copper from chalcopyrite has shifted more and more into direction where copper is smelted by custom smelters far away from copper mines (Jukka and Likka, 2005).

The first commercial plant for chalcopyrite treatment started at the Rancher's Bagdad Mine in 1968 with a production capacity of 6,000 tons per annum. The first large plants was bought into operation in Zambia to produce 100,000 tons per annum in 1973 and by 1980 new plants were on stream in the USA, Mexico and Chile to produce a total production capacity of approximately 180,000 tons per annum. Today, there is a total world market potential of
20.4 million tons which costs at 110 US dollar per ton (Seward, 2001).

\section{Chalcopyrite Ore Extraction Techniques}

\subsection{Mining of Chalcopyrite}

Chalcopyrite is a common mineral and is found in almost all sulfide deposit and is often disseminated through igneous rock (Haver and Wang, 1971). For lower grade deposit located near the surface, the open - pit method is the most practical for the mining of large tonnages of material. Large track mounted drill of ore is prepared for blasting and the broken ore is hauled to the ore dressing plant by truck (at up to 150 tons per load) or conveyor. In underground mining, vertical shaft are sunk well over 1,000 metre $(3,300$ $\mathrm{ft}$ ) below the surface and channels are extended to the ore body. The ore, broken by drilling and blasting is hoisted through the shaft and conveyed to the processing plant. In some cases, primary crushing takes place underground and in others, a ramp and trucks carry ore to the surface (McGraw-Hill, 1998).

\subsubsection{Factors Affecting the Mining of Chalcopyrite}

Factors which may contribute to the decision to mine or not to mine chalcopyrite mineral resources include the following:

(a) The availability of the rock or ore is obviously necessary: When mining begins, the richest sources of ore are mined first and lower grade ore is mined later. So, as time passes, the cost of mining tend to goes up and this was the case with iron mining and phosphate in Tennessee.

(b) The availability of alternative sources of materials also affects decision to mine: The discovery of vast amount of bird guano in South America in the late $19^{\text {th }}$ Century destroyed the Saltpeter industry in Tennessee.

(c) Change of technology affects mining decisions: The making of tools from chart stopped when iron tools were introduced. The quarrying of dimension limestone practically stopped when techniques of making and using cement improved.

(d) Governmental policy also affects decision of mining: Saltpeter mining flourished Tennessee in early $19^{\text {th }}$ Century as a result of large-scale US government purchase of saltpeter to make gunpowder for the war of 1812 .

(e) Pollution either in the mining or from the use of the finished product can affect mining decisions, either by increasing the cost of production or by increasing the demand for the product (Rotuska and Chimjelen iki, 2008).

\subsection{Chalcopyrite Ore Processing}

The first step in the chalcopyrite processing is to liberate the copper minerals and remove waste constituents such as alumina, limestone, pyrite and silica so that the copper and non-ferrous mineral values are concentrated into a product 
containing between 20 to 30 percent copper. The second step involves either smelting or leaching to remove a large proportion of impurity particularly iron and in the case of sulfides ore, sulphur. The final step, refining, removes the last traces of the impurity elements and produces a copper product of 99.99 percent purity (McGraw-Hill Encyclopedia, 1998).

Once the chalcopyrite concentrate containing copper and other metals of value (such as gold, silver) has been produced, the next step is to remove impurity element. In older processes, the concentrate containing between $56-10$ percent water, is first roasted in a cylindrical, refractory lined furnace of either the hearth or fluidized bed type. As concentrate is fed into the roaster, it is heated by a stream of hot air to about $590^{\circ} \mathrm{C}$. Volatile impurities such as arsenic, mercury and some of the sulphur are driven off, the sulphur being removed as sulphur dioxide $\left(\mathrm{SO}_{2}\right)$. What remains is an oxidized product containing a percentage of sulphur that is sufficiently low for s melting. Th is is traditionally done in a reverberatory or electric furnace into which concentrate is fed along with a suitable amount of flux. These are heated by combusted fuel or electrical current to a temperature of $1230^{\circ} \mathrm{C}-1300^{\circ} \mathrm{C}$, producing an artific ial copper iron sulfide that settles in a molten pool at the bottom of the furnace (McGraw-Hill, 1998).

In the roaster, the copper concentrate (chalcopyrite) is partially oxidized to produce alkaline $\left(\mathrm{Cu}_{2} \mathrm{~S}\right)$ and sulphur dioxide $\left(\mathrm{SO}_{2}\right)$ gas. The chalcopyrite ore is heated strongly with silicon - dioxide (silica) and air or oxygen in the furnace or series of furnaces. The copper (II) ion in the chalcopyrite is reduced to copper (I) sulfide which is reduced further to copper metal in the final stages. The iron in the chalcopyrite ends up converted into an iron (II) silicate slag which is removed. Most of the sulfur in the chalcopyrite turns to sulfur dioxide gas. This is used to make sulfuric acid via the contact process (copper extraction and purification). Overall equations for these series of steps are:

$$
\begin{aligned}
& 2 \mathrm{CuFeS}_{2}+2 \mathrm{SiO}_{2}+4 \mathrm{O}_{2} \longrightarrow \mathrm{Cu}_{2} \mathrm{~S}+2 \mathrm{FeSiO}_{3}+3 \mathrm{SO}_{2} \\
& 2 \mathrm{CuFeS}_{2(\mathrm{~s})}+3 \mathrm{O}_{2} \longrightarrow 2 \mathrm{FeO}+2 \mathrm{CuS}+2 \mathrm{SO}_{2}
\end{aligned}
$$

The copper (I) sulfide is converted to copper with a final blast of air.

$$
\mathrm{Cu}_{2} \mathrm{~S}+\mathrm{O}_{2} \longrightarrow 2 \mathrm{Cu}+\mathrm{SO}_{2}
$$

As of 2005, roasting is no longer common in chalcopyrite concentrate treatment. Thus, direct smelting using the following smelting technologies: flash smelting, Noronda, USA s melting, Mitsubishi or EL Temento furnace are in use till date.

\subsubsection{Smelting Process (Pyrometallurgy)}

Pyrometallurgical practice typically involves smelting converting, anode casting and electro-re fining of the anodes to high purity copper metal. The smelting and refining processes used well established technologies are energy efficient and have high metal recoveries including those of gold and silver (Yin et al. 1995). This begin with a dry concentrate containing less than one percent water, which along with flux is contacted in a furnace by a blast of oxygen or oxygen enriched air (McGraw-Hill Encyclopedia, 1998). Pyrometallurgical extraction involves heating the mineral cake in a blast furnace; oxygen pressure and temperature are carefully controlled. The first stage involve the separation of copper and iron ore (Equation 7), followed by the addition of silica $\left(\mathrm{SiO}_{2}\right)$ to the blast furnace to convert iron (II) oxide to a less dense liquid layer of slag, iron (III) silicate which is poured off.

$$
\begin{aligned}
2 \mathrm{CuFeS}_{2}+4 \mathrm{O}_{2} & \longrightarrow \mathrm{Cu}_{2} \mathrm{~S}+2 \mathrm{FeO}+2 \mathrm{SO}_{2(\mathrm{~g})} \\
\mathrm{FeO}_{(\mathrm{l})}+\mathrm{SiO}_{2}(\mathrm{~s}) & \longrightarrow \mathrm{FeSiO}_{3}
\end{aligned}
$$

The calcine is then mixed with silica and limestone and smelted at $1200{ }^{\circ} \mathrm{C}$ (in an exothermic reaction) to form a liquid called copper matte. This temperature allows reactions to proceed rapidly, and allow the matte and slag to melt, so that they can be tapped out of the furnace. During smelting, several reactions occur. For example, iron oxide and sulphide are converted to slag which is floated off the copper matte:

$$
\mathrm{FeO}+\mathrm{SiO}_{2} \longrightarrow \mathrm{FeOSiO}_{2}(\mathrm{l})
$$

In a parallel reaction, the iron sulphide is converted to slag:

$$
2 \mathrm{FeS}+3 \mathrm{O}_{2}+2 \mathrm{SiO}_{2} \longrightarrow 2 \mathrm{FeO} \cdot \mathrm{SiO}_{2}+2 \mathrm{SO}_{2}(\mathrm{~g})
$$

The slag is discarded or reprocessed to recover any remain ing copper. In the $3^{\text {rd }}$ stage of extraction, copper (I) sulphide is reduced to copper metal upon reaction with oxygen air:

$$
\mathrm{Cu}_{2} \mathrm{~S}+\mathrm{O}_{2} \longrightarrow 2 \mathrm{Cu}+\mathrm{SO}_{2}
$$

Depending on the composition of the concentrate, it is possible to carry out smelting autogenously. That is, without the use of auxiliary fuel as is required in reverberatory or electric arc smelting. In addition to reducing the consumption of fuel, the new processes produce relatively low volumes of gas which being high in sulfur dioxide is usually carried out in separate furnace to ensure that the final smelter product reaches the level of 99.5 percent copper that is required for electrolytic refining. At this point, the copper is cast into anode, the shape and weight of which are dictated by the particular electrolytic refining (McGraw-Hill, 1998).

\subsubsection{Leach ing Process (Hydrometallurgy)}

Hydrometallurgy is applied to the rest of the world's primary copper production, objected main ly on oxide and/or low grade copper ore due to significantly lower operating cost (Dresher, 2001). Treatment chain in hydrometallurgy processes are usually consisted of crushing, leaching (non-oxidative leaching, solvent extraction and electrowinning). Hydrometallurgical processing can be effectively applied to oxidized ores containing $\mathrm{CuO}, \mathrm{Cu}_{2} \mathrm{O}$, carbonate and some silicates and rarely for sulphide ore with chalcocite and covellite as predominant copper mineral 
(King, 2007; Stevanovic et al. 2009).

Beginning of solvent extraction process development objected on metal extraction from leach solutions, date from the $60 \mathrm{~s}$ of last century. Beforehand, solvent extraction processes were used in analytical chemical assaying (Habashi, 2007). Hydrometallurg ical methods are used in countries having readily available deposit with low copper content and with surplus of oxidized forms at the same time (USA, Chile, Australia and Peru). The most important development in copper hydrometallurgy with respect to the growing number of its application as well as for its future potential has been solvent extraction process. It becomes the achievement which revolutionized copper production all over the world and enabled to introduce hydrometallurgy for industrial scale (Stevanovic et al. 2009). Occasionally, it is adopted in preference to smelting or pyrometallurgy and is carried out at lower temperatures and thus eliminates the generation of sulfur dioxide. There are, however, effluents and residues that must be treated in order to protect environment. In the hydrometallurgical processes, the ore or concentrate (chalcopyrite) is brought into close contact with a leach solution (frequently sulfuric acid) that dissolves the copper and leaves a residue of gangue (and frequently precious metals). Various system, some quite complex are used to bring copper minerals into contact with the leach solution, wash and filter the residue and finally purify the solution to remove dissolved iron and other impurities (Mc Graw-Hill, 1998). So me experimental hydrometallu rgic al techniques to process chalcopyrite are be ing investigated, but as of 2009 are unproven outside the laboratories. So me rod leach or pressure leach process exist to solubilise chalcocite concentrate and produce copper cathode fro $m$ the resulting leach solution, but this is a minor part of the market.

\subsubsection{Chloride Leaching}

Only chloride of metal in a high valence state such as ferric or cupric will leach metal from their sulfides because oxidation is necessary. Of the numerous chloride routes, ferric chloride $\left(\mathrm{FeCl}_{3}\right)$ leach ing of chalcopyrite concentrates which was initiated by the U.S. Bureau of Mines, Reno Metallurgy Research Center in 1969 received significant attention (Philips, 1976).

\subsection{Intec Copper Process}

The intec copper process is a proven, patented hydrometallu rgical process for the extraction of pure copper and precious metal from sulphide concentrates. The process is based on the electrolytic deposition at the cathode of LME (London Metal Exchange). Grade A purity copper from a purified sodium chloride, sodium bromide electrolyte during electrowinning; the mixed halide species $\mathrm{BrCl}_{2}$ is generated, characterized when it is re-circulated to treat incoming concentrate feed (Crest, 2000).

\section{Description of Intec Copper Process}

The patented intec copper process was developed for the recovery at LME Grade A purity from sulfide concentrates. Essentially, the intec copper process consists of the three sequential circuits: leaching, purification and electrowinning. A simple flow diagram for the intec copper process is shown in Fig. 6.

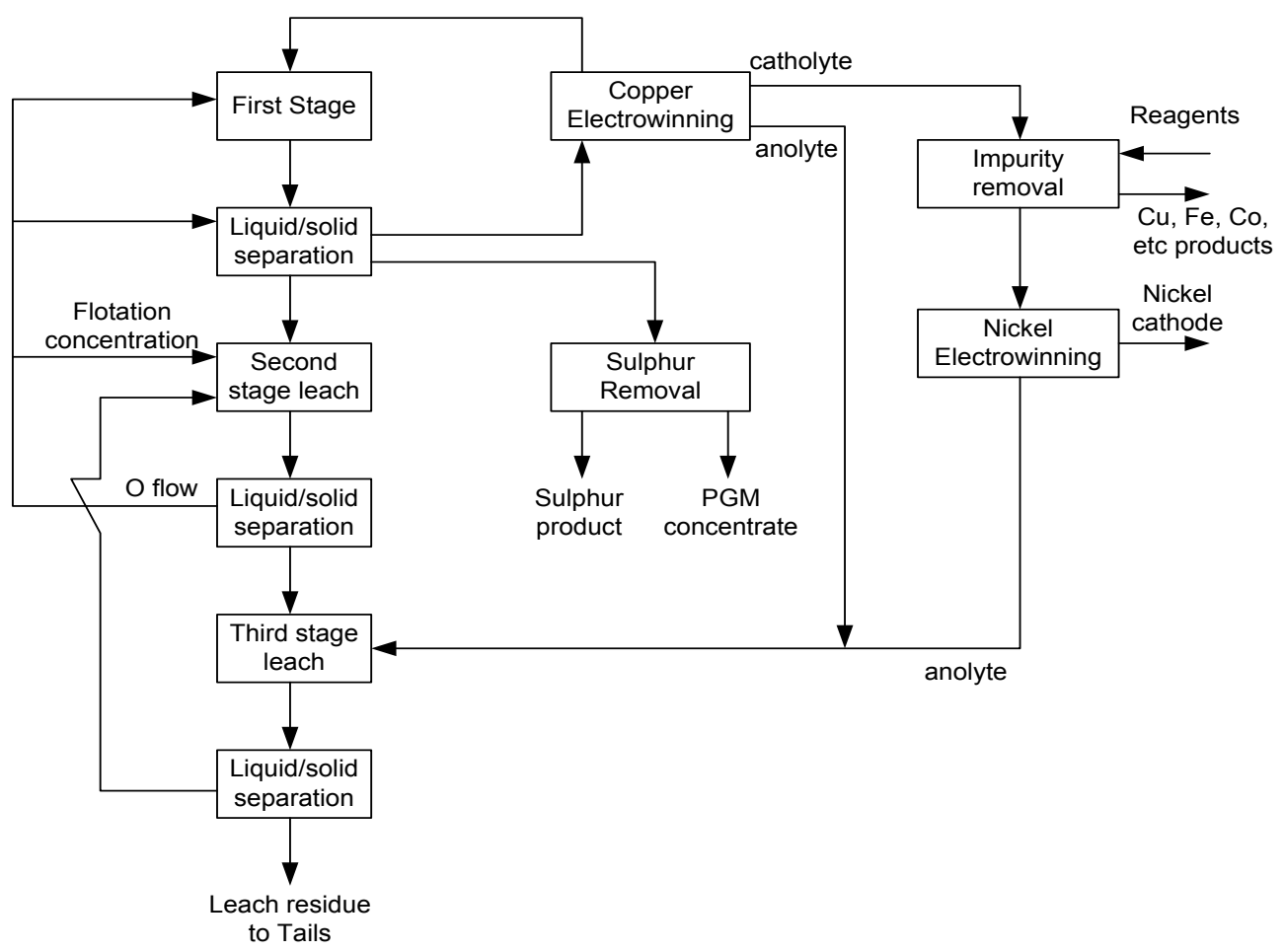

Figure 6. Conceptual block diagram for PGM and base metal recovery by the intec process (Crest, 2000) 


\subsection{The Cuprex Process}

The cuprex process leaches chalcopyrite concentrate at atmospheric pressure with ferric chloride solution in two stages. The pregnant liquor containing copper, iron and minor amount of impurities mainly zinc, lead and silver is sent to the extraction stage of the SX circuit where it is contacted at ambient temperature with a kerosene solution DS5443. The copper, selectively transferred to the organic phase is extracted in three stages. The aqueous solution of copper chloride is then sent to the electrolysis section as catholyte, which is fed to the cathode compartment of an electrowinning cell to produce granular copper. Electrowinning of copper from chloride solution take place in a diaphragm cell where the cathode and anode compartment are separated by a rein forced cation-selective ion-exchange membrane. Chlorides generated at the anode is recovered and used to deoxidize the cuprous chloride generated in the catholyte during electrowinning.

\subsubsection{Pressure Sulfate Leaching}

Thermodynamically favorable at an elevated pressure, the use of high pressure in chalcopyrite concentrate leaching has led to a reliable and cost competitive process option. A strong resurgence of interest in the pressure sulfate leaching of chalcopyrite concentrates occurred after developments in construction of materials, more efficient mills for fine or ultrafine grind ing of sulfides and success ful implementation of autoclave technology for zinc and refractory metals (Jones, 1999). Based on the literature data for sulfide leaching especially chalcopyrite in an oxidizing acidic medium and the characterization of the leach liquor and residues obtained, the following chemical reactions were chosen to study $\mathrm{CuFeS}_{2}, \mathrm{H}_{2} \mathrm{SO}_{4}, \mathrm{NaNO}_{3}$ and $\mathrm{H}_{2} \mathrm{O}$ systems. The main reactions include:

$\mathrm{CuFeS}_{2}+4 / 3 \mathrm{NaNO}_{3}+8 / 3 \mathrm{H}_{2} \mathrm{SO}_{4}$

$$
\longrightarrow \mathrm{CuSO}_{4}+\mathrm{FeSO}_{4}+2 / 3 \mathrm{H}_{2} \mathrm{SO}_{4}+2 \mathrm{~S}^{\mathrm{O}}+4 / 3 \mathrm{NO}+8 / 3 \mathrm{H}_{2} \mathrm{O}(12)
$$

$\mathrm{CuFeS}_{2}+4 \mathrm{NaNO}_{3}+\mathrm{H}_{2} \mathrm{SO}_{4}$

$$
\longrightarrow \mathrm{CuSO}_{4}+\mathrm{FeSO}_{4}+2 \mathrm{Na}_{2} \mathrm{SO}_{4}+2 \mathrm{~S}^{\mathrm{O}}+4 \mathrm{NO}_{2}+4 \mathrm{H}_{2} \mathrm{O}
$$

$\mathrm{CuFeS}_{2}+5 / 3 \mathrm{NaNO}_{3}+\mathrm{H}_{2} \mathrm{SO}_{4}$

$$
\longrightarrow \mathrm{CuSO}_{4}+1 / 2 \mathrm{Fe}\left(\mathrm{SO}_{4}\right)_{3}+5 / 6 \mathrm{Na}_{2} \mathrm{SO}_{4}+2 \mathrm{~S}^{\mathrm{O}}+\mathrm{NO}_{2}+\mathrm{H}_{2} \mathrm{O}(14)
$$

$\mathrm{CuFeS}_{2}+5 \mathrm{NaNO}_{3}+5 \mathrm{H}_{2} \mathrm{SO}_{4}$

$$
\longrightarrow \mathrm{CuSO}_{4}+1 / 2 \mathrm{Fe}\left(\mathrm{SO}_{4}\right)_{3}+5 / 2 \mathrm{Na}_{2} \mathrm{SO}_{4}+2 \mathrm{~S}^{\mathrm{O}}+5 \mathrm{NO}_{2}+5 \mathrm{H}_{2} \mathrm{O}(15)
$$

\subsubsection{The CESL Process}

The CESL process is a divergent approach to low pressure oxidation in which a high proportion of sulfide (sulphur) remain in the elemental form in leach residue (McCunn et al. 2004). This process also employ a chloride enhanced oxidative pressure leach in a controlled amount of acid designed to convert the copper to a basic copper sulfate salt, the iron to haematite and sulfur to elemental sulfur. The flow diagram of a CESL process is shown in Fig. 7.

\subsubsection{Dynatec Process}

The dynatec process involves oxidative leaching of chalcopyrite concentrate at $150^{\circ} \mathrm{C}$ using coal at a modest dosage (25 kg/t of concentrate) as an effective anti-agglomerant (Collins and Kofluk, 1998). Sulfide oxidation chemistry is similar to the CESL process. A high extraction of copper (98\%) is achieved by either recycling the unleached sulfide to the leach after the floating and removal of elemental sulfur (melting and filtration) or pre-treating the concentrate with a fine grinding (+90 $25 \mu \mathrm{m})$.

\subsection{Total Pressure Oxidation}

The total pressure oxidation uses water as the leach medium and converts most of the sulfide sulfur to copper sulfate and sulfuric acid (King et al. 1994). Reground concentrates is slurried in acidic recycle solution and pumped into the first compartment of an autoclave operated at $210-220^{\circ} \mathrm{C}$, with sparked oxygen to maintain $700 \mathrm{kPa}$ of over pressure. Basic iron sulfate (hydroniumjarosite) is a significant co-product which will collect silver and other monovalent cation.

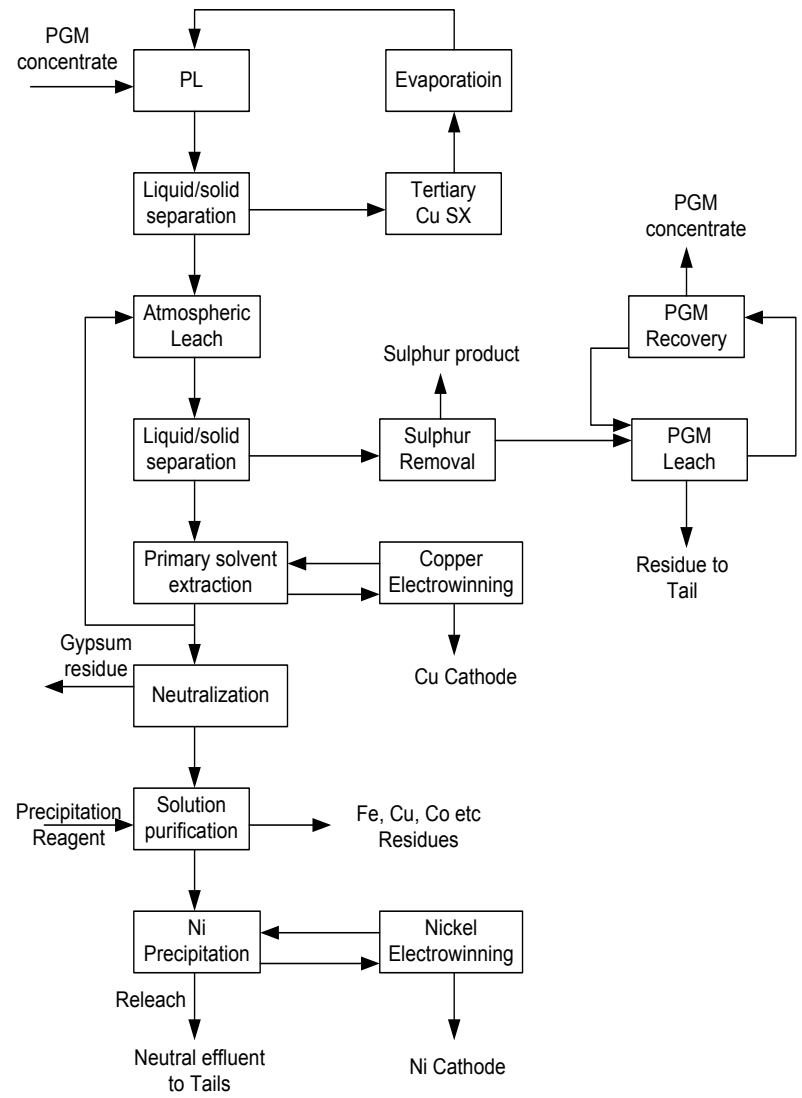

Figure 7. Schematic drawing of the column leach apparatus (Dresher, 2004)

\subsubsection{Brisa Process}

Brisa process is based on bioleaching by indirect mechanis $m$ which involves two separate biological and chemical stages. In the chemical stage, chalcopyrite 
concentrate are leached with ferric sulfate at $12 \mathrm{~g} / \mathrm{L}$ and $\mathrm{pH}$ 1.25 in the agitated reactors using silver as a catalyst. Higher copper extraction ( $>95 \%$ wt) is obtained by activating concentrates with $2 \mathrm{mg} \mathrm{Ag} / \mathrm{g}$ of concentrate at $70^{\circ} \mathrm{C}$ and 10 hours leaching (Dresher, 2004).

\subsubsection{The Biocop (TM) Process}

BHP Billiton and Codelco built a demonstration plant at Chuquicamata in North Chile (Dresher, 2004). This was constructed in a stirred reactor containing dilute sulfuric acid into which air is blown, hydrothermophilic microorganis $\mathrm{m}$ which operate at a temperature between $60^{\circ} \mathrm{C}$ and $90^{\circ} \mathrm{C}$ are used. Leaching of chalcopyrite concentrate is complete within 10 days (Dresher, 2004).

\subsubsection{The Bac Tech/Min itek Process}

Bac Tech and Minitek working in conjunction with industries Penoles SA de CV, operated a $2.2 \mathrm{c} / \mathrm{d}$ demonstration plant for the bioleaching of copper concentrate in Monterrey, Mexico (Miller, 1999). Conducted in a series of counter current reactors, the thermophilic microorganisms are used at temperature of 25 $-55^{\circ} \mathrm{C}, \mathrm{pH} 0.5-2.5$ is maintained within the reactors. Carbon dioxide is obtained from ambient air, nutrients are added to the leach liquor and retention time is about 30 days. The plant employs moderate thermophilic to oxidize the sulfides followed by conventional SX-EW to recover the contained copper, which achieved recovery rate of $96.4 \%$ and a residency period of six days (Dresher, 2004)

\section{Dissolution Kinetic Studies on Chalcopyrite Ores}

Various reported works on the dissolution kinetics and solvent extraction of copper from chalcopyrite ores are discussed thus. It is important to note that limited data in this area of research from Nigeria origin has been documented (Olubambi et al. 2006). These authors did not address some kinetic parameters such as activation energy (Ea), reaction order, Arrhenius constant etc. for the better prediction of the dissolution mechanism that could be used in the selective and purification of copper from the ores by solvent extraction technique.

A study reported by $\mathrm{Lu}$ (1982) studied the effect of chloride ions on the dissolution of the mineral in oxygenated acid solution and they concluded that the presence of sodium chloride $(\mathrm{NaCl})$ in the leaching solution promoted the formation of porous sulphur layer, favouring the diffusion of the leaching reagents through the film product of the reaction continuation in the surface of the mineral. Winand (1991) also studied the addition of sodium chloride $(\mathrm{NaCl})$ in the copper sulphide leaching that attributed to the formation of copper chloride complex ion as being a decisive factor for increasing the leaching rate for increasing the copper solubility in the system $\mathrm{Cl}^{-} / \mathrm{Cu}$ (II) and/ or $\mathrm{Cu}$ (I). He suggested that $\mathrm{NaCl}$ act on the elemental sulphur layer and also on the solubility of copper comp lexes in the reaction system with aim to improving the copper extraction from the sulfide mineral in a relatively short time with low operation cost, taking into consideration the influence of a cationic surfactant.

Vania-Mori et al. (2009) studied the advantages of copper sulphide CTAB (Cetyl-three-ethyl ammonium bromide) on the electro-leaching of copper sulfide (chalcopyrite) flotation concentrate. The result of the electro-leaching process shared that extraction of copper in the presence of surfactant cation CTAB had an increased extraction compared to the results of the one without CTAB. The test shows evidence that the electro-leaching process makes possible the production of chlorate ion that dis solves the copper sulphides releasing copper ion to solution, which are simultaneously reduced in the cathode surface.

Olubambi et al. (2006) studied the leaching of zinc and copper from Nigeria bulk sulfide ore with sulfuric acid in the presence of hydrogen peroxide $\left(\mathrm{H}_{2} \mathrm{O}_{2}\right)$, with the aim to investigate the effectiveness of hydrogen peroxide as an oxidant for the sulfuric acid. The results of this study have shown that sulfuric acid leaching in the presence of hydrogen peroxide is an effective route for copper and zinc recovery from Nigerian comp lex sulfide ore.

The dissolution process in the presence of $\mathrm{H}_{2} \mathrm{O}_{2}$ has been investigated by both Jiang et al. (2002) and Adebayo et al. (2003). The dissolution take place in two reaction stages; viz: the dissolution of elemental sulphur and its conversion to sulfate $\left(\mathrm{SO}_{4}{ }^{2-}\right)$ which can be expressed as follows:

$$
\begin{gathered}
\text { Stage I: } \mathrm{CuFeS}_{2}+2 \mathrm{H}_{2} \mathrm{SO}_{4}+\mathrm{O}_{2} \\
\qquad \mathrm{CuSO}_{4}+\mathrm{FeSO}_{4}+2 \mathrm{~S}^{0}+2 \mathrm{H}_{2} \mathrm{O} \\
\text { Stage II: } \mathrm{S}^{\mathrm{O}}+1.5 \mathrm{O}_{2}+\mathrm{H}_{2} \mathrm{O} \longrightarrow 2 \mathrm{H}^{+}+\mathrm{SO}_{4(\mathrm{aq})}
\end{gathered}
$$

The first stage of the proposed reaction mechanism which is the sulfuric acid leaching is very slow and was enhanced by the addition of hydrogen peroxide. When the very reactive sulfide radical fro $\mathrm{m}_{2} \mathrm{O}_{2}$ comes in contact with the highly reactive sulfide mineral, elemental sulfur is formed.

$$
2 \mathrm{HO}^{*}+2 \mathrm{~S}^{2-} \longrightarrow 2 \mathrm{~S}^{0}+\mathrm{H}_{2} \mathrm{O}+0.5 \mathrm{O}_{2}
$$

and then the elemental sulphur is later oxidized to sulphate ions.

$$
2 \mathrm{~S}^{\mathrm{o}}+3 \mathrm{O}_{2}+2 \mathrm{H}_{2} \mathrm{O} \longrightarrow 2 \mathrm{SO}_{4}{ }^{2-}+4 \mathrm{H}^{+}
$$

When copper or zinc react with sulfate, copper sulfate and zinc sulfate are formed, which are very soluble and dissociated in aqueous solutions:

$$
\begin{aligned}
& \mathrm{Cu}^{2+}{ }_{(\mathrm{aq})}+\mathrm{SO}_{4}{ }^{2-}{ }_{(\mathrm{aq})} \longrightarrow \mathrm{CuSO}_{4(\mathrm{aq})} \\
& \mathrm{Zn}^{2+}{ }_{(\mathrm{aq})}+\mathrm{SO}_{4}{ }^{2-}{ }_{(\mathrm{aq})} \longrightarrow \mathrm{ZnSO}_{4(\mathrm{aq})}
\end{aligned}
$$

The slow copper dissolution rate from chalcopyrite has been attributed to the formation of a passivating layer on the mineral surface (Cordoba et al. 2009). Based on this, several works in terms of theories and hypothes is have been proposed.

Burkin (1969) suggested that the leaching of chalcopyrite 
with $\mathrm{Fe}^{3+}$ favours the formation of a diffusion film over its surface made of a semi-conductor bimetallic sulfide with chemical and structural properties different from chalcopyrite. Those intermediate products that proceed from the solid state transformation favour the solubilization of cations from the crystal lattice at different rates. The models assume that the chemical reaction does not take place on the interface but across the thickness of the reaction phase.

The proposal by Ammou-Chokroum et al. (1977) showed that the copper dissolution rate is controlled by the formation and evolution of a compact diffusion layer of a copper polysulfide (less reactive) and with less iron content than the original chalcopyrite. The thickness of that layer would be the result of two opposite reactions viz; the formation of a copper passive layer because of the slower diffusion of copper than iron in solid state obeying a parabolic law and the dissolution of the passivating layer according to a linear law in which a porous film of elemental sulfur is formed.

Munoz et al. (1979) gave a new interpretation of the phenomenon. They consider that the limiting step of the chalcopyrite dissolution with ferric ion is the transport of electrons needed for the cathode reduction reaction through an insulating layer of elemental sulfur. In this model, elemental sulfur formed established a physical barrier between the anodic and cathodic zone, limiting the redox reaction of chalcopyrite leaching. Hack et al. (1995) compliment Ammou-Chokroum et al. (1977) model which proposed a mixed model of diffusion and chemical control to explain the passivation of chalcopyrite in sulfate medium.

According to Abraitis et al. (2004) on acid leaching and dissolution of major sulfides ore mineral process and galvanic effect on complex system, it was concluded that the rate of acid dissolution of metal sulphide in mixed mineral system can be dramatically affected by galvanic effects with rates increasing by factor as great as 30 times in some cases and that the combination of conventional bulk leaching experiment with surface analysis techniques can lead to new insight into the mechanis $m$ of the dissolution through an understanding of reaction stoichiometry.

Previous US Bureau of mines (USBM) research on the leaching of chalcopyrite with ferric sulfate $\left[\mathrm{Fe}_{2}\left(\mathrm{SO}_{4}\right)_{3}\right]$ demonstrated that surfactant addition enhance chalcopyrite $\left(\mathrm{CuFeS}_{2}\right)$ leaching and that surfactant selection has a significant impact on the initial leaching rate (Schultz et al., 1995).

Dutrizac and MacDonald (1971) studied chalcopyrite leaching using $0.1 \mathrm{M} \mathrm{Fe}_{2}\left(\mathrm{SO}_{4}\right)_{3}-0.1 \mathrm{M} \mathrm{H}_{2} \mathrm{SO}_{4}$ (sulfuric acid). They reported a rapidly decreasing leaching rate in the absence of chloride. When $6 \mathrm{~g} / \mathrm{L}$ chloride is added, leaching becomes linear. Such behaviour suggests a change in leaching mechanism. They also reported that there is no leaching enhancement for chloride additions when the temperature is less than $50{ }^{\circ} \mathrm{C}$. Muniz - Ribadeneira and Gomberg (2001) also reported that $0.05-1.0 \mathrm{~N} \mathrm{NaCl}$ (sodium chloride), 0.29 to $58 \mathrm{~g} / \mathrm{L}$ imp roves copper leaching at 23 to $25^{\circ} \mathrm{C}$ in $1 \mathrm{~N} \mathrm{H}_{2} \mathrm{SO}_{4}$.

Murr et al. (2006) reported that both $\mathrm{NaCl}$ and $\mathrm{KCl}$ (potassium chloride) improve chalcopyrite leaching at $\mathrm{pH}$ 2.0 and $28^{\circ} \mathrm{C}$. It was agreed that $\mathrm{KCl}$ enhances chalcopyrite leaching, but attributed the effect to potassium rather than chloride. This study also reported that the over potential (a measure of resistance to oxidation) developed during oxidation of sulfides in a sulfate system is not observed in chloride system. The reason for this could be attributed to chloride functioning as an electron transfer agent. Such behaviour was concluded to enhance leaching in an oxidation - reduction reaction by facilitating transfer of the electron from the species being oxidized.

Mujina et al. (2008) leached chalcopyrite in acidic $\mathrm{Fe}_{2}\left(\mathrm{SO}_{4}\right)_{3}$ and $\mathrm{FeCl}_{3}$ solution and found that $\mathrm{S}^{0}$ formed on chalcopyrite grain surfaces in both experiments, but the $\mathrm{S}^{0}$ formed in $\mathrm{Fe}_{2}\left(\mathrm{SO}_{4}\right)_{3}$ was denser than that formed in $\mathrm{FeCl}_{3}$. This could be contributed the slower oxidation rate determined for $\mathrm{Fe}_{2}\left(\mathrm{SO}_{4}\right)_{3}$ leaching compared to that for $\mathrm{FeCl}_{3}$ leaching.

Hundstrom et al. (2005) examined an investigation of chalcopyrite $\left(\mathrm{CuFeS}_{2}\right)$ dissolution in cupric chloride solutions. The results obtained determined that the dissolution of a stationary chalcopyrite sample was controlled by diffusion in the reaction product layer at $\mathrm{pH} 3$ and changing to chemical rate control at $\mathrm{pH} 1$. The $\mathrm{FeOOH}$ formation in addition to the elemental sulphur favours chalcopyrite dissolution. Al-Harahsheh (2008) used ferric chloride leaching of copper from chalcopyrite. The effect of stirring speed and temperature on chalcopyrite leaching were investigated. Agitation was found to have a negative effect on cupric ion, the fact that cupric complexes are formed during the leaching process where the cupric ion is considered as a string oxidant.

Jiang et al. (2002) studied the dissolution kinetic of manganese silver associate ores and found that hydrogen peroxide greatly increase sulfuric acid recovery of silver. The reaction order of $\mathrm{H}_{2} \mathrm{SO}_{4}$ and $\mathrm{H}_{2} \mathrm{O}_{2}$ was determined as 0.80 and 0.68 , respectively. Silver leaching was found to be diffusion - controlled by the following kinetic model:

$$
1-\mathrm{b} \alpha-(1-\alpha)^{\mathrm{b}}=\mathrm{Kt}
$$

where $\alpha=$ the mole fraction of the ore dissolved, $t=$ time in minutes, $\mathrm{k}=$ mass transfer coefficient.

Antonijevic et al. (2004) on the other hand, studied the dissolution kinetics of chalcopyrite by hydrogen peroxide in sulfuric acid. Copper recoveries were found to be significantly increased as the concentration of sulfuric acid and hydrogen peroxide increased. Nevertheless, all these research studies have been centered on high grade ore and none on low-grade complex as in the case of Nigerian ore.

The anodic dissolution of chalcopyrite was studied by Jordan and Vargas (2009) with an electrochemical technique that allows direct measurement of anodic dissolution current in small chalcopyrite particles. Their approach enabled to analyze chalcopyrite dissolution kinetic 
according to the shrinking core model and to propose a mechanis $\mathrm{m}$ for the control of the dis solution rate.

More recently, several researchers have pointed out that high redox potentials promote passivation of chalcopyrite during leaching. Hiroyoshi et al. (2001) proposed a reaction mode which involves the intermediate reduction of chalcopyrite to $\mathrm{Cu}_{2} \mathrm{~S}$ and oxidation of ferrous ion, followed by the oxidation of $\mathrm{Cu}_{2} \mathrm{~S}$ by ferric ion to cupric ion and elemental sulfur. Also, Nicol and Lazaro (2003) proposed that chalcopyrite reduction can be achieved by protonic attack at potential value lower than $0.4 \mathrm{~V}$ releasing $\mathrm{Cu}^{2+}$, $\mathrm{Fe}^{2+}$ and $\mathrm{H}_{2} \mathrm{~S}$. Then hydrogen sulfide is oxidized by ferric ion to cupric ions and elemental sulfur. According to this model, the rate of $\mathrm{H}_{2} \mathrm{~S}$ decreases with increasing chalcopyrite surface potential from $0.5 \mathrm{~V}$ to $0.7 \mathrm{~V}$. Previous to this works, other authors had also found better chalcopyrite dissolution rates at relatively low potential (Kametani and Aoki, 1985; Barr et al., 1992; Third et al., 2000; Third et al., 2003 and Okamoto et al., 2003).

Recent studies by Bryn et al. (2010) on kinetic data for chalcopyrite dissolution shows how multiple linear regressions was performed to determine the dependence of $\log$ rate on the independent variable: $\log \left[\mathrm{H}^{+}\right], \log \mathrm{PO}_{2}$, $\log [\mathrm{Fe}(\mathrm{III})]$ and $\log \left[\mathrm{Cl}^{-}\right]$.

Cordoba et al. (2008) have shown that the passivation of chalcopyrite is related to high potential value (e.g. high $\mathrm{Fe}^{3+} / \mathrm{Fe}^{2+}$ ratio). It was concluded that the leaching solution of ferric/ferrous sulfate reach rapidly an equilibrium at which the activities of both ions are equal and related to a critical potential of approximately $0.65 \mathrm{~V}$ vs SHE. Thus, when the redox potential is in itially very high, there is the tendency to equilibrium that favours the fast precipitation of ferric ion as jarosite and then the passivation of chalcopyrite.

\subsection{Microbial Leaching Studies on Chalcopyrite}

Biohydrometallurgy treatments have been practiced extensively for metal recovery from low-grade sulfide bearing materials (Maouf, 1971). The thiobacillus ferrooxidans which is responsible for metal dissolution derives the necessary energy for its life process from oxidation of ferrous iron (Silverman, 1967) and reduced valence inorganic sulfur compounds (Silver and Torma, 1974) and thus utilizes carbon dioxide for growth when cultured on metal plates.

Most studies to date, Biswas and Davenport (1980) and Torma et al. (1972) have been concentrated on improving both the kinetic of copper dissolution by using a large number of bioleaching species (mesophilic and moderately or extremely thermophilic microorganisms, and the knowledge of how certain physical factor (particle size, temperature, $\mathrm{pH}$, catalyzing ions) affect the process. The results thus far obtained have made possible to establish the most suitable conditions for carrying out the bioleaching process, but have not revealed the cause which bring about a decrease in the extraction rate after certain time.

Gomez et al. (1995) used culture which is principally formed for Thiobacillus ferroxidans, Thiobacillus thioxidans and leptosipinillum ferooxidans. The result of their investigation showed that the reactivity of the chalcopyrite gradually increase with the bacterial treatment. Karanam et al. (2007) carried out bioleaching studies on periolatin columns using low-grade copper containing rock (granite). The experiment made use of lixiviant consisted of acidified ferric sulfate containing acidophilic microorganis $\mathrm{m}$. Leaching parameters studied were lixiviants flow rate, particle size, and bed height. The results showed that the leaching efficiency increases with decrease in particle size and lixiviant flow rate.

According to Nowaczyk et al. (1998), the Thiobacillus ferrooxidans bacterial for processing copper and iron leaching from chalcopyrite from (Kotlina Ktodska) was investigated. Their results showed that the leaching of metals from chalcopyrite occurs according to the following reactions:

$$
\begin{array}{ll}
\mathrm{CuFeS}_{2}+5 / 4 \mathrm{O}_{2}+5 \mathrm{H}^{+} \longrightarrow \mathrm{Fe}^{2+}+2 \mathrm{~S}+\mathrm{Cu}^{2+}+5 / 2 \mathrm{H}_{2} \mathrm{O} \\
\mathrm{S}+\mathrm{H}_{2} \mathrm{O}+3 / 2 \mathrm{O}_{2} \stackrel{\text { Bacteria }}{\longrightarrow} \mathrm{SO}_{4}^{2-}+2 \mathrm{H}^{+}
\end{array}
$$

From this study, the process can be described as a first order reaction inhibited by the product according to the following equations:

$$
-\frac{d x}{d t}=K_{1} x-K_{2}\left(x_{o}-x\right)
$$

$\mathrm{x}_{0}$ and $\mathrm{x}$ are the initial and current concentration of the substrate, respectively. Therefore,

$$
x=\frac{x_{0}}{k_{1}+k_{2}}\left[k_{2}+k_{1} \ell^{\left(k_{1}+k_{2}\right)\left(t_{o}-t\right)}\right]
$$

From the latter equation, the kinetic parameters of the reaction were calculated: the rate constant of leaching $\left(\mathrm{k}_{1}\right)$, the inhibition rate constant $\left(\mathrm{k}_{2}\right)$ and the induction period $\left(\mathrm{t}_{\mathrm{o}}\right)$ (Nowaczyk et al., 1998). The results obtained in this study allow a conclusion that the proposed kinetic model can be used for optimization of the process parameter using thiobacillus ferrooxidans bacteria.

Many researchers (Konishi et al., 1999; Torress et al., 1995, and Howard and Guindwell 1999) reported that thermophile macroorganism such as sulfolobus acidiamus and metallosphaera have been shown to leach chalcopyrite to high extraction at temperature range $65-75^{\circ} \mathrm{C}$, both in shakes flask and stirred tanks. The success of thermophile over mesophiles has not yet been clearly explained, but it has been observed that thermophile leaching takes place in a fairly low potential environment $(380-500 \mathrm{mV} \mathrm{Ag} / \mathrm{AgCl})$ in which chalcopyrite passivation is not observed (Petersen et al., 2001; Gank et al. 2001; Third et al., 2000). 
Table 1. Summary of some other reported works by different authors on copper extraction from various chalcopyrite ore sources by hydrometallurgical processing

\begin{tabular}{|c|c|c|c|c|c|c|}
\hline \multirow[b]{2}{*}{ References } & \multirow[b]{2}{*}{ Sources } & \multirow[b]{2}{*}{ Leachant used } & \multicolumn{3}{|c|}{ Parameters evaluated } & \multirow[b]{2}{*}{ Conclusions } \\
\hline & & & $\begin{array}{c}\text { Ea, } \\
\text { kJmol }\end{array}$ & $\begin{array}{c}\text { Reaction } \\
\text { Order } \\
\end{array}$ & $\begin{array}{c}\text { Arrhenius } \\
\text { Constant } \\
\end{array}$ & \\
\hline $\begin{array}{l}\text { Antonijevic } \\
\text { et al. (2004) }\end{array}$ & $\begin{array}{l}\text { Bor River, East } \\
\text { Serbia }\end{array}$ & Sulfuric Acid & ND & ND & ND & $\begin{array}{l}\text { Grain Size has a minor influence on the } \\
\text { leaching rate of the mineral in } \mathrm{H}_{2} \mathrm{SO}_{4} \\
\text { and } \mathrm{Cu}^{2+} \text { concentration in the leaching solution } \\
\text { was maximum after } 3 \text { hours. }\end{array}$ \\
\hline Lin ( 2003$)$ & China & Ferric Chloride & ND & ND & ND & $\begin{array}{l}\text { The elemental sulfur formed during the } \\
\text { leaching is crystalline in nat ure. }\end{array}$ \\
\hline $\begin{array}{l}\text { Padilla et al. } \\
\text { (2007) }\end{array}$ & Chile & $\begin{array}{l}\mathrm{H}_{2} \mathrm{SO}_{4} \text { acid- }-\mathrm{O}_{2} \\
\text { media }\end{array}$ & ND & ND & ND & $\begin{array}{l}\text { Selective dissolution from sulfidized } \\
\text { chalcopyrite obtained at } 100^{\circ} \mathrm{C} \text { and oxygen } \\
\text { over pressures of about } 304 \mathrm{kPa} \text { in less than } 3 \\
\text { hour of residence time. However, for longer } \\
\text { times, iron extraction increases rapidly and } \\
\text { selectively decreases. }\end{array}$ \\
\hline $\begin{array}{l}\text { Ting-sheng et } \\
\text { al. (2007) }\end{array}$ & $\begin{array}{l}\text { Tongling of } \\
\text { Anhui } \\
\text { Province, } \\
\text { China }\end{array}$ & $\begin{array}{l}\text { Low Oxygen } \\
\text { NaOH, } \mathrm{H}_{2} \mathrm{O} \\
\text { Vitriol. }\end{array}$ & 15.22 & 0.647 & ND & $\begin{array}{l}\text { (i) The rate increase with } 2 \text { and } 4 \text { times of } 10 \mathrm{~K} \text {. } \\
\text { (ii) } \mathrm{K} \text { det ermined using } \\
\qquad \log \mathrm{K}=\mathrm{In} \mathrm{A}-\frac{\mathrm{Ea}}{2.303 \mathrm{RT},} \\
\qquad \log \frac{k_{1}}{k_{2}}=\frac{\mathrm{E} a}{2.303}\left(\frac{1}{T_{2}}-\frac{1}{T_{1}}\right) \\
\text { and concluded that the dissolution of } \\
\text { chalcopyrite is controlled by chemical reaction. }\end{array}$ \\
\hline $\begin{array}{l}\text { Mustafa and } \\
\text { Aliosman. } \\
\text { (2010) }\end{array}$ & $\begin{array}{l}\text { Murgul-Arluin, } \\
\text { Turkey }\end{array}$ & $\mathrm{H}_{2} \mathrm{SO}_{4}$ & ND & ND & ND & $\begin{array}{l}\text { Copper dissolution is controlled by limit } \\
\text { diffusion. It was found that } \mathrm{Fe}_{2} \mathrm{O}_{3} \text { addition } \\
\text { before the calcination also contributes to the } \\
\text { copper dissolution. }\end{array}$ \\
\hline $\begin{array}{l}\text { Sokic et al. } \\
\text { al.(2008) }\end{array}$ & Rudnik, Serbia & $\begin{array}{l}\text { DT A and T G } \\
\text { Measurement }\end{array}$ & ND & ND & ND & $\begin{array}{l}\text { The relatively high values of Ea indicates that } \\
\text { the chalcopyrite concentrate oxidat ion process } \\
\text { occur in the kinet ic area. }\end{array}$ \\
\hline $\begin{array}{l}\text { Sargsyan and } \\
\text { Hovhanisyan. } \\
\qquad(2010)\end{array}$ & Not stated. & $\begin{array}{l}\text { Thermogravimetric } \\
\text { Method }\end{array}$ & ND & ND & ND & $\begin{array}{l}\text { Roasted before hydrometallurgical processing } \\
\text { of chalcopyrite, copper concentrate should be } \\
\text { carried out at temperat ure not above } 676^{\circ} \mathrm{C} \text { in } \\
\text { order to produce soluble solfatic roasted } \\
\text { product. }\end{array}$ \\
\hline $\begin{array}{l}\text { Tomasz } \\
(2007)\end{array}$ & $\begin{array}{l}\text { Lumbin mine, } \\
\text { South-West } \\
\text { Poland }\end{array}$ & $\mathrm{H}_{2} \mathrm{SO}_{4}$ & ND & ND & ND & $\begin{array}{l}\text { (Max demand for acid) } \\
\text { Non-oxidat ive leaching shale rich middling } \\
\text { appeared to be very rapid at } 30 \text { and } 60 \mathrm{~min} \text { and } \\
\text { select ive process exhibiting remarkable pH } \\
\text { changes as a process controlling parameters. }\end{array}$ \\
\hline $\begin{array}{l}\text { Mari et al. } \\
\quad(2005)\end{array}$ & Espio, Finland & $\begin{array}{l}\text { Cupric chloride } \\
\text { (solution) }\end{array}$ & ND & ND & ND & $\begin{array}{l}\text { In concentrated } \mathrm{CuCl}_{2} \text { solution, cupric ions } \\
\text { were assumed to be at least partially not in a } \\
\text { chloro-complex form. Whereas cuprous ion } \\
\text { readily form complex in chloride solution. }\end{array}$ \\
\hline $\begin{array}{l}\text { Vania et al. } \\
\quad(2008)\end{array}$ & Not stated. & $\begin{array}{l}\text { Electrolytic process } \\
\text { using CT AB } \\
\text { (cethyl-three-ethyl) } \\
\text { ammonium bromide }\end{array}$ & ND & ND & ND & $\begin{array}{l}\text { Development of an electrolytic process for } \\
\text { treat ing a copper sulfide flot at ion concentrate } \\
\text { mostly chalcopyrite }\left(\mathrm{CuFeS}_{2}\right) \text { and Bornite } \\
\qquad\left(\mathrm{Cu}_{5} \mathrm{FeS}_{4}\right) .\end{array}$ \\
\hline $\begin{array}{l}\text { Acero et al. } \\
\text { (2009) }\end{array}$ & $\begin{array}{l}\text { Molar } \\
\text { Catalonian } \\
\text { Coastal range, } \\
\text { Spain }\end{array}$ & $\begin{array}{l}\text { Long-time flow } \\
\text { through experiment } \\
\mathrm{HCl} \text { and } \mathrm{H}_{2} \mathrm{SO}_{4}\end{array}$ & ND & ND & ND & $\begin{array}{l}\text { The steady state rate is det ermined by } \\
r=\frac{q\left(l i-l i^{0}\right)}{A \gamma} . \text { Error associated with } \\
\text { dissolution is calculated by Gausian error } \\
\text { propagation method. }\end{array}$ \\
\hline $\begin{array}{l}\text { Schultze et } \\
\text { al. (1995) }\end{array}$ & $\begin{array}{c}\text { Colorado, } \\
\text { Eastern U.S.A. }\end{array}$ & $\begin{array}{l}\mathrm{H}_{2} \mathrm{SO}_{4} / \\
\mathrm{Fe}\left(\mathrm{SO}_{4}\right)_{2}\end{array}$ & ND & ND & ND & $\begin{array}{l}\text { The experiments verify the enhancement due to } \\
\text { chloride and surfactant addition in the leaching } \\
\text { system of chalcopyrite and } \mathrm{H}_{2} \mathrm{SO}_{4} \text {. }\end{array}$ \\
\hline
\end{tabular}

$\mathrm{ND}=$ Not Det ermined 
The future of biomining is challenging, as it offers advantages of operational simplicity, low capital and operational cost and shorter construction which no other alternative process can provide. In addition, minimum environmental impact and the use of this technology in the mining industry are set to increase. Once commercial scale, high - temperature processes have been designed, the variety of mineral that will become acquiescent to bio-mining will increase. Although, the viability of microbes that flourish at temperature $55{ }^{\circ} \mathrm{C}$ is not yet well-proven commercially, it appears that one can isolate iron and/or sulfur-oxidizing organisms for whatever temperature is required (Mohd et al., 2009).

In summary, some other reported works from the literature on the hydrometallurgical processing of chalcopyrite ores from various parts of the globe is presented in Table 1.

From Table 1, it is important to note that no reported works of chalcopyrite ore processing from Nigerian orig in has been made.

\section{Conclusions}

Hydrometallu rgical treat ment of chalcopyrite $\left(\mathrm{CuFeS}_{2}\right)$ is a growing technology (Hyvarinen and Hamalainen 1999). In recent times, attention has been drawn to low-grade complex sulfide ores due to the decline in the world deposits of high - grade ores. Complex sulfide ores are in many cases difficult to treat with conventional mineral processing method and the concentrate produced is often not clean enough. This seriously limits their commercial value (Fan et al. 2005). Differential flotation does not release all the constituent phases and so the different concentrates obtained are of poor quality with low metal recovery. This makes further pyro metallurg ical processing of these ores very difficult and costly (Hyvarinen et al. 2003) and rendered them difficult to commercialize. Consequently, the metal value is preferably extracted directly from the low grade ores through hydrometallurgical process (Hiroyoshi et al. 2001). The basis of hydrometallurgy is justified not only by economical, but also ecological reasons. Increasing demand of industry for metals leads to a quick exhaustion of the best or the easiest accessible resources which stimulate the search for new environmental - friendly solutions such as bio-hydrometallurgy to enable exploitation of poor deposit or recovery of metal from industrial wastes.

In general, experiences have been shared based on various researches on hydrometallurgical process and now we find that many deposit around the world that have previously not been regarded as suitable for economic exploitation are being re-considered and this will hopefully lead to the valuable economic regeneration of other minera logical areas.

In conclusion, it is pertinent to note that there are two main methods employed worldwide for processing chalcopyrite for metal production. The most important one is the conventional - pyrometallurgy method comprised numerous types of shaft and flash technologies, which consists of crushing, grinding, flotation, smelting refining and electro-refining. This method is applied to sulfide flotation concentrates rather than ores and is economically feasible for copper rich feed for large scale operations. A second method, hydrometallurgy is applied to the rest of the world's primary copper production. Hydrometallurgy consists of crushing, leaching (non-oxidation leaching, atmospheric leaching and pressure leaching), solvent extraction and electrowinning and can be effectively applied for oxidized ores as well as for sulfide ores with chalcopyrite as a predominant copper mineral. In general, due to interests that include environmental aspects and the possibility of increased exploitation of mixed and lower grade ores and relatively small isolated deposits, there has been a worldwide upsurge of interest in hydrometallu rgical process for the production of copper.

\section{ACKNOWLEDGEMENTS}

A. A. Baba wishes to thank University of Ilorin for permission to honour CSIR-TWAS Fellowship a ward; Prof. B. K. Mishra, Director, Institute of Minerals and Materials Technology, Bhubanes war-751013, India for the acceptance as CSIR-TWAS Postdoctoral Fellow; the Management, Academy of Sciences for the Developing World, Trieste, Italy and Council of Scientific and Industrial Research, New-Deh li for the A ward of 2010 CSIR-TWAS Fellowship for Postdoctoral Research (May, 2011-January, 2012).

\section{REFERENCES}

[1] Abraitis, P. K., Pathrick, R. A., Kelsall, G. H., and Vaughan, D.J., 2004, "Acid leaching and dissolution of major sulphides. Process and galvanic effect in complex system," Mineralogical Magazine, 68, 343 - 351.

[2] Acero P., Cama J., Ayora C., and Asta, M. P., 2009, "Chalcopyrite dissolution rate law from $\mathrm{pH}$ 1-3". Geologica Acta 7(3), 389-397.

[3] Adebayo, A. O., Ipinmoroti, R. O., and Ajayi, O. O., 2003, "Dissolution kinetic of chalcopyrite with hy drogen peroxide in sulphuric acid medium". Chemical and Biochemical Engineering Quarterly, 17(3), 213 - 218.

[4] Al-Harahsheh, C. G. F., 2008, "Ferric chloride leaching of chalcopyrite synergetic effect of $\mathrm{CuCl}_{2}$," Hydrometallurgy, $91,89-97$.

[5] Ammou-Chockruum, M., Cambazogiu, M. and Steinmez, D., 1977, "Oxydation menagee de la chalcopyrite en solution aude," Analyse Imetique de reactions II Modeles diffusionales. Bull. Soc. Fr-Mizer Cristallegr, 100, 161 177. 
[6] Antonijevic, M. M., Jankovic, Z.D., and Dimtrijevic, M. D., 2004, "Kinetic of chalcopyrite dissolution by hydrogen peroxide in sulphuric acid," Hydrometallurgy, 71, 329 - 334.

[7] Barr, D. W., Jordan, M. A., Norris, P. R., and Philips, C.V., 1992, "An investigation into bacterial cell, ferrous iron, $\mathrm{pH}$ and Eh interaction during thermophilic leaching of copper concentrates," Miner Eng. 5, 57 - 567.

[8] Bergy, L. G. and J. B. Yianatos, J. B., 2001, "Current status of copper SX/EW plant control," Minerals Engineering, 14 (9), 975 - 985.

[9] Biswas, A. K., and Davenport, W. G., 1980, "Extractive metallurgy of copper," Pergamon Press Oxford, 263 - 269.

[10] Brantley, S. L., 2003, "Reaction kinetics of primary rock-forming minerals under ambient conditions," In Drever, J. I. (Ed)., Treatise on Geochemistry Vol. 5 (Holland, H.D., Turekian, K.K, Exec. Eds.) Elsevier, pp. 73 - 117.

[11] Bryn, E., Kimbali, J., Donal, R., and Susan B. L., 2010, "Chalcopyrite dissolution rate law," Applied Geochemistry $25,975-983$.

[12] Burkin, A. R., 1969, "Solid state transformation during leaching," Miner. Science En gin eering, 1, 4 - 14.

[13] Chuck, P., and Virginia, B., 2011, The Mineral Chalcopyrite, Mineral specimens, gems, jewelries and gifts, Minerals, http://www.minerals-n-more.com/Chalcopyrite_Info.html, Accessed: 12/06/2011.

[14] Collins, M. J., and Kofluk, O. K., 1998, U.S. Patent 5, 730 776.

[15] Cordoba, E. M., Munoz, J. A., Blazquez, M. L., Gonzalez, F., and Ballester, A., 2008, "Leaching of chalcopyrite with ferric ion. Part II: Effect of redox potential," Hydrometallurgy, 93, 81-87.

[16] Cordoba, E. M., Munoz, J. A., Blazquez, M.L., Gonzalez, F., and Ballester, A., 2009, "Passivation of chalcopyrite during its chemical leaching with ferric ion at $68^{\circ} \mathrm{C}$," Minerals Engineering, 22, 229 - 235.

[17] Crang, J. R., and Vanghan, D. J., 1994, Ore microscopy and ore petrography, $2^{\text {nd }}$ Edition, Wiley Interscience, New York.

[18] Crest, A., 2000, Intec copper process: Environmental Technology Assessment. Department of Chemical Engineering, University of Sydney, The Metal and Material Journal. 5, 2001-2004

[19] Dixon D. G., and Dreisinger, D. B., 2003, The Modelling of the Sepan Autoclave Process. Report to Lane Xang Mineral (Laos).

[20] Dresher, W. H., 2001, "How hydrometallurgy and SX-EW process made copper the 'Green' Metal," Hydrometallurgy, $6,120-140$.

[21] Dresher, W. H., 2004, Producing Copper Nature's Way. Bioleaching CWD Innovation, p. 10.

[22] Dutrizac, J. E., and MacDonald, R. J. C., 1979, "Reaction mechanism for the acid ferric sulphate leaching of chalcopyrite," Metallurgical Transaction B-Process Metallurgy, 10 (2), 149 - 148

[23] Fan, X., Peng, J., Huang, M., Zang, S., and Zhang, L., 2005, "Study on innovative process of leaching of chalcopyrite,"
Journal Mining and Metallurgical Engineering, 25 (3), 58 62 .

[24] Gank, M., Pinches, A., and Van Royen, J. V., 2001, "Bioleaching of a chalcorpyrite concentrates, using an extremely thermophile culture international," Journal Mineral Processing, 62, 243 - 255.

[25] Gomez, G., Munoz, J. A., Sevillano, M. E., Ballester, A., Figwewa, M., Gonzalez, F., and Blazquez, M. L., 1995, "Microbial effect on the anodic dissolution of chalcopyrite" Proceeding of the XIX International Mineral Processing Congress Physical and Chemical Processing, Vol. 2, Chapter $1,217-221$.

[26] Habashi, F., 2007, "Copper Metallurgy at the Crossroads", Journal of Mining and Metallurgy, 43B, 1-19.

[27] Hackl, R. P., Dreisinger, D. B., and King, J. A., 1995, "Passivation of chalcopyrite during oxidative leaching in sulphate media," Hy drometallurgy, 29, 25 - 48.

[28] Haver, R. R., and Wang, M. M., 1971, "Recovery of copper, iron, and sulphur from chalcopyrite concentrates using a ferric chloride leach," J. Metals, 23 (2), 25 - 29.

[29] Hershel, F., 2011, "Chalcopyrite mineral" The mineral and gemstone kin gdom, (C) Copyright 1997 - 2011. http://www.m inerals.net/mineral/chalcopyrite.aspx, Accessed: 18/02/2011.

[30] Hiroy oshi, N., Miki, H., Hirajima, T., and Tsunekawa, M., 2001, "Enhancement of chalcopyrite leaching by ferrous ions in acidic ferric sulphate solutions," Hydrometallurgy. 60 , $185-197$.

[31] Howard, D., and Guindwell, F. K., 1999, “A kinetic study of the leaching of chalcopyrite with sulphobus metallicus," In: Anils. R. and Ballester A. (Eds) Biohydrometallurgy and Environmental toward the Mining of the $21^{\text {st }}$ Century - art A Elsiever Amsterdam. pp. 209 - 217.

[32] Hundstrom, M., Aromaa, J., Forsen, O., Hyvarinen, O., and Micheal H. B., 2005, "Leaching of chalcopyrite in cupric chloride solution: Hydrometallurgy production of copper from concentrates with nitrogen species catalyzed pressure leaching solvent extraction and electrowinning," Paper Presented at the ALTA 2000 SX/IX Forum Adelaide South Australia, October, 2000.

[33] Hyvarinen, O., and Hamalainen, M.U.S., 2009, Patent U.S. 6,007,600 (December, 1999).

[34] Hyvarinen, O., Hamalainen, M., Leimala, M. and Outokumpu R., 2003, "Hydrocopper process: A novel concept in copper production," Chloride Metallurgy, Montreal, Canada, 19 - 23.

[35] Jiang, T., Yiang, Y., Zhang, B. and Huang, Z., 2002, "Kinetic of silver leaching from manganese-silver associated ores in sulphuric acid solution in presence of hydrogen peroxide" Metallurgical and Materials Trans., B. 33B, 813 816.

[36] Jones, D., 1999, CESL Copper Process, Presentation at the Copper Concentrate Treatment Short Course Held in Conjunction with Copper 99-Cobre 99 Phoenix, AZ, 9 - 13.

[37] Jordan, H., and Vargas, T., 2009, "Modeling the kinetics of anodic dissolution of chalcopyrite based on electrochemical measurement conducted on chalcopyrite particle electrodes". The Mining and Material Journal 12(1), 8140 - 8165. 
[38] Jukka, T., and Likka, V. K., 2005, "Blister Flash smelting-efficient and flexible low cost continuous copper process," The Journal of the Mineral, Metal, Material Society, 8, 271-282.

[39] Kametani, H. and Aoki, A., 1985, "Effect of suspension potential on the oxidation rate of copper concentrate in a sulfuric acid solution," Metal Trans B. 16B, 69 pp.

[40] Karanam, S. R., Annita, M., Devbrata, P., Gautam, R. C., Ertupti, K. M., Lola, D.S., and Baradak, M., 2007, "Parcolation bacteria leaching of low-grade chalcopyrite using acidophilic microorganism," Euranian Journal of Chemical Engineering, 25 (3), 524 - 530.

[41] King, J. A., Dreisinger, D. B. and Knight, D.A., 1994, "The total pressure oxidation of copper concentrates" Presentation of the CIMM District 6 Meeting, Vancouver, B.C.

[42] King, M. G., (2007), Journal of Mining and Metallurgy Section B. 59(2), 21.

[43] Konishi, Y., Saturu, A., and Tokushige, M., 1999, "Kinetics of bioleaching of chalcopyrite concentrate by acidophilic," Thermophile Acidanus Brierleyi Biothechnol. Prog., 15, 681 -688 .

[44] Lin, H. K. 2003 'Characterization and flotation of sulfur from chalcopyrite concentrate leaching residues'. Journal of Minerals, Materials Characterization and Engineering, 2(1), 1-9.

[45] Lu, Z. Y., 1982, "Passive and transpassive anodic behaviour of chalcopyrite in acid solution," Metallurgical Transactions, B. $13 \mathrm{~B}, 571-579$.

[46] Majima, H., Awakura, Y., Hirato, T., and Tanaka, T., 1985, "The leaching of chalcopyrite in ferric chloride and ferric sulfate solution," Can. Metal. Quart, 24, 283 - 291.

[47] Maouf, E. E., 1971, "The role of micro organism in chemical mining," Min. Eng. (23), 43 - 46.

[48] Mari, L., Jari A., Olof, F., Olli, H., and Barker, M. H, 2005, "Leaching of chalcopyrite in cupric chloride solution", Hydrometallurgy, 77(1-2), 89-95

[49] Matgos J. X., Martins, L. and Rosa, C., 2003. "Pargal Mineiro ta cova dos Mouro IGM contribute for the sustainable development of the mining part I" GEM Pub. Musea Geom. N2, 487 - 494.

[50] McCunn et al., 2004, "CESL process-moving from pilot to production scale", Presentation at the International Hydrosuphides 2004, Saintiago Chile, $16-19$.

[51] McGraw-Hill, 1998, Encylopedia of Science and Technology, Longman, Toky o, 180, 420-452.

[52] Miller, P., 1999, "Bioleaching of copper concentrates: Presentation at the Cooper Concentrate Treatment Short Course Held in Conjunction with Copper '99", Cobre '99 Phonex AZ.

[53] Mohd, H. S., Ashish, K., Kavindra, K. K., and Jamala, M. A., 2009, "A useful approach toward metal extraction," American Eurasion Journal of A gronomy, 2(2), 84 - 88.
[54] Mujina, P., Bertschinger, H. J., Asa, C. S., Calle, P. P., and Long, J. A., 2008, "Leaching chalcopyrite in acidic $\mathrm{Fe}_{2} \mathrm{SO}_{4}$ and $\mathrm{FeCl}_{3}$ " Geological Acta. 3, 15 - 26.

[55] Muniz - Ribadeneira, F. J., and Gomberg, H. J., 2001, "Kinetic of dissolution of chalcopyrite in sulphuric acid. and sodium chloride," Hydrometallurgy 36(2), 89 - 96.

[56] Munoz, P. B., Miller, J. D. and Wadsworth, M. E., 1979, "Reaction mechanism for the acid ferric sulphate leaching of chalcopyrite,”M Metall. Trans. B. 10B, 149 - 158.

[57] Murray, J. W., Balistrieri, L. S. and Alldredge, A. L., 2006, "Investigation of chalcopyrite dissolution in $\mathrm{NaCl} / \mathrm{KCl}$ saturated solution: Evolution of surface feature and kinetic rate". Geochimica et Cosmochimica Acta 65 (10), 1430 1439.

[58] Mustafa, G., and Aliosman A, (2010) “Dissolution of copper from a primary chalcopyrite ore calcine with and without $\mathrm{Fe}_{2} \mathrm{O}_{3}$ in sulphuric acid solution". Indian Journal of Chemical Technology, 17, 142-149

[59] Nesse, W. D., 2000, "Introduction to mineralogy," Oxford University Press, Oxford, 1 - 10.

[60] Nevada, O., 2011, Chalcopyrite mineral facts, The Gem and Mineral Collectors, Photo Gallery, http://nevada-outback -gems.com/mineral_information/Chalcopyrite_mineral_info. htm. Access: 11/04/2011.

[61] Nicol, M. J., and Lazaro, I., 2003, "The role of non-oxidation processes in the leaching of chalcopyrite copper", In: Riveros P.A., Dixon, D., Dresigner, D.B., Menacho J. (eds). Hydrometallurgy of copper, Book 1, Vol. 6, Santiago, Chile pp. 367 - 381.

[62] Nowaczyk, K., Jusczak, A., Donka, F., and Speka, J., 1998, "The use of Thiobacillus ferrooxidans bacteria in the process of Chalcopyrite leaching," Polish Journal of Environment Studies, 7 (5), 307 - 312.

[63] Olubambi, P. A., Borode, J. O., and S. Ndlove, S., 2006, "Sulphuric and Leaching of Zinc and Copper from Nigerian Complex Sulphide Ore in the Presence of Hydrogen Peroxide," Journal of the South African Institute of Mining and Metallurgy,106, $765-770$.

[64] Okamoto, H., Nakayama, R., and Hiroyoshi, M., 2003, "Improvement Chalcopyrite leaching in acidic sulfate solution by redox potential control," Copper Book I, Vol. VI, Santiago Chile. pp. 67 - 81.

[65] Padilla, R., Vega, D., and Ruiz, M. C., 2007. "Pressure leaching of sulfidized chalcopyrite in sulfuric acid-oxygen media". Hydrometallurgy, 86, 80-88.

[66] Petersen, J. D., Zimmins, M. J. G., and Ruintenberg, R.., 2001, "Batch reactor studies of the leaching of a pyrite/chalcopyrite concentrate using thermophilic bacteria," In Cinirelli, V.S.T., and Garica Jr, O. (Eds). Biochydrometallurgy fundamentals technology and sustainable development - part A. Elseiver Amsterdam. pp. $526-533$.

[67] Philips, T. A., 1976, "Economic Evaluation of a Process for Ferric Chloride Leaching of Chalcopyrite Concentrate by Mires IC 8699" 22. 
[68] Pletcher, D., Walsh, F. C., and Kluwer, D., 1993, Industrial Electrochemistry, $2^{\text {nd }}$ Edition.

[69] Rotuska, K., and Chimjeleniki, T., 2008, "Growing role of solvent extraction in copper ore processing physics," Resources in the Economy, 42, 29 - 36.

[70] Sargsyan, L. E., and Hovhanisyan, 2010. "Investigation of chalcopyrite cuprum concentrate roasting by thermogravimetry and differential thermal analysis". Metallurgical and Minig Industry, 2(3), 225-229

[71] Schultze, L. E., Sandoval, S. P., and Bush, R. P., 1995, "Effect of Additives on Chalcopyrite Leaching" (Report of Investigation 9556), United States Department of the Interior, United State Bureau of Mines.

[72] Seward, G. W., 2001, Leach, SX-EW production of copper A Global View, Zenela-China Symposium, 10pp.

[73] Silver, M., and Torma, A. E., 1974, "Oxidation of metal sulphides by Thiobacillus ferrooxidans grown on different substrates," Canadian Journal of Microbiology, 20, 141 147.

[74] Silverman, M. P., 1967, "Mechanism of bacteria pyrite oxidation," Journal of Bacteriol, 94, 1046 - 1051.

[75] Sokic, M., Ilic I., Zivkovic D., and Vuckovic N., 2008, "Investigation of mechanism and kinetics of chalcopyrite concentrate oxidation process". Metalurgija, 47(2),109-113.

[76] Sokic, M. D., Markovic B. R., and Zirkovic D. T, 2009. Kinetic of chalcopyrite leaching by sodium nitrate in sulphuric acid. Hydrometallurgy, 95, 169-182

[77] Stevanovic, Z., Antonijevic, M., Jonovic, R., Auramovic, L. J., Markovic, R., Bulgaria, M., and Trujic, V., 2009. "Leach-SX-EW Revalorization from Over burden of abandoned copper Mine, Cerovo Eastern Serbia," Journal of Mining and Metallurgy 45B(1), 45-47.

[78] Szymanowski, J., 1996, "Copper hydrometallurgy and extraction from chloride media," Journal of Radio-analytical and Nuclear Chemistry, 28(1), 183-194.

[79] Third, K. A., Cord-Ruwiseh, R., and Watling, H. R., 2000, "Control of the redox potential by oxygen limitation improves bacterial leaching of Chalcopyrite". Biotechnol. Bioema, 78(4), 433 - 441.

[80] Third, K. A., Cord-Ruwiseh, R., and Watling, H. R., 2003, "The role of iron-oxidizine bacteria in stimulation or inhibition of chalcopyrite bioleaching". Hydrometallurgy, 57, $225-233$

[81] Thomas, A., 2009, "Improved process for chalcopyrite leaching," Ibridge link idea and innovation. http://www.ib ridgenetwork. org/ucb/improve process for chalcopyrite. Acessed: 17/12/2010.
[82] Ting-sheng, Q., Guang-hua, N., Jun-feng, W. and Li-feng, C, 2007, "Kinetic process of oxidative leaching of chalcopyrite under low oxygen pressure and temperature" Transferrous Met. Soc. China, 17, 418-422.

[83] Tomaz, C., 2007. "Non-oxidative leaching of black shale copper ore from Lubin mine", Physicochemical Problem of Mineral Processing, 41, 325-335.

[84] Torma, A. E., Walden, C. C., Duncan, D. W., and Bramon, B. M. R., 1972, "The effect of carbondioxide and particle surface area on the microbiology" Bioengineering, 14, 777 -780 .

[85] Torress, F., Blazquez, M. L., Gaonzales, F., Ballester, A., and Mier, J. L., 1995, "The bioleaching of different sulphides concentrate using thermophile bacteria," Metallurgy Transaction, B., 26B, 455 - 465.

[86] USGS, 2009, Facts about Copper: Copper uses, resources, supply, demand and production information, http://eology. com usgs uses-of-copper/. Accessed: 15/12/2010.

[87] Vania, M., Maro, A. S., Paulo A., and Medeiro S., 2008, "The advantage of CTAB (cetyl-three ethyl ammonium bromide) use on the electroleaching of copper sulphide flotation concentrate". The Mineral, Metal and Material Society, 207-212

[88] Varna-mori, J., Marco, A. S., Aguisar, P. Q., Paulo, A., Medeiros da Silva, Elvis, G. S., and Sobral, P. Q., 2009, "The Advantages of CTAB (Cetyl-three-Ethyl ammonium Bromide) use on the electroleaching of copper sulphides flotation concentrate," Hy drometallurgy, 2, 116 - 132.

[89] Wikipedia: The Free Encylopaedia, Copper, http://en. ikipedia.org/wiki/Coppery

[90] Winand, R., 1991, "Chloride Hydrometallurgy". Hydrometallurgy, 27, 285 - 316.

[91] Woods, R., and Doyle, F. M., 2000, "Electrochemistry in mineral and metal processing," (Proceeding of the $5^{\text {th }}$ International Symposium from the $197^{\text {th }}$ Meeting of the Electrochemical Society, Toronto, Canada, 14, $200-214$.

[92] Yin, Q. Z., Amelin, Y., Nagashima, S. S., Russell, E. R., Scott, D., Thrane, K., and Yurimoto, H., 1995, “Atmospheric and electrochemical oxidation of the surface of chalcopyrite $\left(\mathrm{CuFeS}_{2}\right)$ ". Geochim. Cosmochim. Acta, 59, 1091-1100.

[93] Young, C., Alfantaz, A., Anderson, C., James, A., Dreisinger, D., and Harris, B., 2003, "Hydrometallurgy", $5^{\text {th }}$ International Conference in Honour of Professor Ian PSitchie. The Minerals, Metals and Material Society, Warrendale, P.A., 2003.

[94] Facts about copper, copper uses, resources, supply, demands and production information (2010) http://geology.com/uses of copper. Retrieved on 23/8/2010. 